CEP Discussion Paper No 931

May 2009

\title{
What if Congress Doubled R\&D Spending on the Physical Sciences?
}

Richard Freeman and John Van Reenen 


\begin{abstract}
Many business, academic, and scientific groups have recommended that the Congress substantially increase R\&D spending in the near future. President Bush's American Competitiveness Initiative calls for a doubling of spending over the next decade in selected agencies that deal with the physical sciences, including the National Science Foundation. We consider the rationale for government R\&D spending in the context of globalization and as an investment in human capital and knowledge creation with gestation times far longer than Federal funding cycles. To assess the impact of a large increase in R\&D spending on the science job market, we examine the impact of the 1998- 2003 doubling of the NIH budget on the bio-medical sciences. We find that the rapid increase in NIH spending and ensuing deceleration created substantial adjustment problems in the market for research and failed to address long-standing problems with scientific careers that are likely to deter many young people from choosing a scientific career. We argue that because research simultaneously produces knowledge and add to the human capital of researchers, which has greater value for young scientists because of their longer future career life span than to older scientists, there is reason for funding agencies to tilt their awards to younger researchers.
\end{abstract}

Keywords: Basic Science, R\&D, labor markets for scientists, globalization JEL Classifications: J23, J45, 030

This paper was produced as part of the Centre's Productivity and Innovation Programme. The Centre for Economic Performance is financed by the Economic and Social Research Council.

\title{
Acknowledgements
}

We would like to thank Scott Stern, Walter Schaffer, Rolf Lehming and seminar participants at the IPE Washington DC conference for helpful comments. The Economic and Social Research Council through the Centre for Economic Performance and the Sloan Foundation through the Science and Engineering Workforce Project have generously funded the research.

Richard Freeman is a Senior Research Fellow, Centre for Economic Performance, London School of Economics. He is also Ascherman Professor of Economics at Harvard University and Programme Director, Labor Studies, National Bureau of Economic Research. John Van Reenen is the Director of the Centre for Economic Performance and Professor of Economics, London School of Economics.

Published by

Centre for Economic Performance

London School of Economics and Political Science

Houghton Street

London WC2A 2AE

All rights reserved. No part of this publication may be reproduced, stored in a retrieval system or transmitted in any form or by any means without the prior permission in writing of the publisher nor be issued to the public or circulated in any form other than that in which it is published.

Requests for permission to reproduce any article or part of the Working Paper should be sent to the editor at the above address.

(C) R. Freeman and J. Van Reenen, submitted 2009

ISBN 978-0-85328-384-3 
In his 2006 State of the Union Address President Bush announced the American Competitiveness Initiative - a program that promised to spend substantial federal moneys to redress perceived US weaknesses in science and technology. One of the centrepieces of the Initiative was a commitment to double basic R\&D spending over the next decade at the National Science Foundation (NSF), Department of Energy's Science Core programs, and the National Institute of Standards and Technology. Another component called for $\$ 4.6$ billion in R\&D tax incentives, intended to induce greater R\&D spending by private firms. Much of the President's proposal was based on the National Academy of Sciences' 2006 "Gathering Storm" report, which called for large increases in federally funded R\&D in physical sciences, among other policies, to keep the US in the forefront of science and technology.

Congress responded to the Competitiveness Initiative by authorizing increased R\&D spending, indicating that it desired to increase R\&D support. But Congress did not appropriate the funds. Failure to appropriate the money reflected partisan disagreements in Washington and the greater importance of other budgetary and political considerations. The result was a modest change in federal spending for R\&D in the physical sciences and stagnant federal support of R\&D overall that reduced spending in real terms. Congress did, however, extend tax incentives for corporate R\&D spending.

Between 2000 and 2006 many studies and reports called for improvements in the country's capacity in scientific and technological activity (Freeman, 2006) by increasing R\&D spending and investing more in science and engineering education. The call for increased resources for science and engineering was based on a widespread belief that "solutions to many of the challenges facing society have their roots in our scientific understanding, where technology increasingly drives the global economic engine, and where many other nations are gaining rapidly in scientific and engineering capabilities" (NSF, 2007). Business leaders particularly in high-tech sectors were worried about increased foreign competition and the decline of comparative advantage in the R\&D intensive sectors of the economy. The science community decried a decreased rate of funding basic research proposals, that "may be negatively impacting the academic research community, resulting in increased workload and diminished S\&E capacity" (IPAMM, 2007) The National Institute of Health (NIH) complained that it could not support as many high quality research proposals as in the past, and NIH and NSF reported that their peer review systems were over-burdened with a growing number of research proposals. The military and defense establishment, whose hires are often limited to US citizens, feared that not enough citizens and residents were choosing science and engineering careers. ${ }^{1}$

Given that most analysts recognized that the career incentives for entering science and engineering were too low to attract more US students, nearly all studies favored educational initiatives to improve science in schools as well as spending increases to boost demand for scientists and engineers. The National Academy of Sciences' Board of

\footnotetext{
${ }^{1}$ An alternative to broad based incentives to increase supply would be for military and defense sectors to attract more US citizen scientists and engineers by raising their pay, which would reallocate more citizens to those jobs even if the number of US-born scientists did not change.
} 
Life Sciences recommended that NIH "take steps to provide PostDocs and early-career investigators with more financial support for their own research and establish programs for new investigators and staff scientists among other mechanisms"(NAS, 2005). The American Academy of Arts and Sciences (2008) report on alternative models for funding the sciences called for funding directed at young investigators and at risky projects that could have high payoffs.

The widespread support for increasing the US investment in science and engineering, particularly in the physical sciences, makes it likely that in the near future Congress will substantially boost $R \& D$ spending. ${ }^{2}$ There are precedents for a surge in R\&D spending to meet perceived national opportunities or needs. In 1998 a bipartisan coalition in Congress pressed the Clinton Administration to increase the R\&D budget substantially, with particular emphasis on the NIH. The coalition favored a doubling of NIH spending over ten years but the Administration chose an even more rapid increase-a doubling in the budget over the next five years. In 2003 the Bush administration completed the doubling, but then kept the budget roughly stable in nominal terms. Earlier, the Soviet sputnik spurred a huge increase in federal R\&D spending between 1956 and 1962. There have been smaller bursts of financial support for particular programs deemed of special national interest in given time periods such as the War on Cancer, Apollo, and the Nano-technology Initiative.

How do large concentrated increases in R\&D spending affect the market for research and the careers of scientists and engineers? How might the government best structure an increase to produce a bigger sustainable research system? Will increased spending improve the job market for young scientists and engineers and attract more Americans into the fields as many hope it will do?

This paper examines these questions. It reviews some of the evidence on the state of science and engineering that motivated the Competitiveness Initiative and the diverse reports that called for increased R\&D spending. Then it assesses the doubling of the NIH budget from 1998 to 2003 and the ensuing deceleration in spending, focusing on the adjustment problems that result from rapid acceleration and deceleration of spending. The $\mathrm{NIH}$ doubling experience provides a warning sign of what might happen in the future to the physical sciences if funding increases for NSF and the other agencies that support the physical sciences in the same manner as funding increased for NIH.

Based on this analysis, we consider ways for the federal government to boost $R \& D$ spending more efficiently in the future. Our main conclusions are:

1. Increased R\&D spending will not by itself resolve problems with the American scientific research endeavor. More funds are necessary but not sufficient to improve the opportunities for young researchers and to place basic research onto a long-term sustainable growth path.

2. One-time surges in spending, which produce a deceleration after the surge, have sizable adjustment costs. Instead of making "doubling" spending a goal, policymakers would do better to determine a desired ratio of R\&D to GDP and to increase funding smoothly to attain that goal. Agencies and universities need "bridge funding" or

\footnotetext{
${ }^{2}$ Indicative of the concern and pressure to increase the national investment in science, in the first week of May 2008450 educators, lobbyists, government officials, and business leaders met in Washington to keep the issue and Competitiveness Initiative in the forefront of policy-makers. (Mervis, 2008)
} 
stabilization policies to buffer research activity from rapid changes in spending.

3.The response of researchers to the incentives built into the number and size of research grants offer determines the effects of spending initiatives on research activity. When a funding agency increases the number and value of research grants, researchers submit more proposals, increasing the amount of research, along a supply curve. When an agency reduces the number of awards, in the short run researchers also respond by making multiple submissions. This stresses the peer review process and stability of the research market. Funding agencies have to balance changes in the number and value of grants carefully to reduce the adjustment costs of changes in budgets.

4. Viewing research grants as investments in the human capital of the researcher as well as in the production of knowledge, funding agencies should support proposals by younger researchers over equivalent proposals of older researchers. The reason is that younger researchers, by which we mean those with 20 or so years of likely future research careers, are more likely to use their increased human capital in future research because they have a longer career ahead of them than older researchers close to retirement.

\section{UNDERSTANDING THE CONCERN The Background}

The U.S. share of science and engineering activity around the world is declining (see Table 1 for an overview). This decline is inevitable as the rest of the world catches up to the US in higher education and R\&D. In 1970, with just $6 \%$ of the world's population the US had $30 \%$ of world's college students and graduated about $40 \%$ of science and engineering PhDs. By 2005, as countries around the world invested heavily in higher education, the US share of college enrollments had fallen to $13 \%$. The U.S. share of the world's science and engineering graduates is, moreover, below its share of all graduates because science and engineering attract large proportions of students overseas than in the US. At the doctorate level, the US share of scientist and engineering degrees fell to $20 \%$ in 2000 and is expected to reach $15 \%$ in 2010 . The US contributed about half of the world's R\&D spending in the 1970s, but this dropped to about a third by 2003.

Partly in response to the growth of scientific and engineering talent around the world, the multinational firms who undertake most industrial R\&D increasingly invest in R\&D outside the US as well as in the US. The large number of scientific and engineering graduates in China and India combined with the lower wages in those countries make them attractive sites for multinational R\&D facilities. In 2004 China reported that multinationals had established over 750 R\&D facilities whereas in 1990, they had none. In 1991 the US spent 13 times as much on R\&D as China. In 2003 it spent 3.4 only times as much (Freeman, 2006).

About $60 \%$ of basic research in the US is conducted in universities, largely funded by the federal government. ${ }^{3}$ The major federal funding agencies for basic research in the physical sciences are the NSF, Department of Defence, Department of Energy, and

\footnotetext{
${ }^{3}$ National Science Foundation, National Patterns of R\&D Resources: 2006 Data Update. Table 2 shows reports that the US spent $\$ 63.6$ on basic research in 2006 and that $\$ 36.9$ billion was in colleges and universities, of which $\$ 24.5$ billion was funded by the federal government (66\%) http://www.nsf.gov/statistics/nsf07331/pdf/tab2.pdf
} 
National Institute of Standards, while the NIH is the main funder of basic research in the biological sciences. The NSF supports over $50 \%$ of the Federal non-medical fundamental research at U.S. colleges and universities. From 1990 to 2006 the share of R\&D funded by the federal government fell from $40.5 \%$ to $28.4 \%$. Compared to GDP federal R\&D fell from $0.112 \%$ to $0.073 \%{ }^{4}$

As the US share of scientists and engineers and R\&D worldwide has trended downward, so too has the US share of scientific publications and citations. Data from the Chemical Abstracts Services shows that in 1980 the US had 73\% of papers in the field whereas in 2003 US researchers had only $40 \%$ of the papers (Freeman, 2006). The US share of science articles published fell from $39 \%$ in 1988 to $29 \%$ in 2005 while the US share of citations dropped from $36 \%$ of articles written in 1992 to $30 \%$ of articles written in 2002 .

Given the demography of the world, the US cannot maintain the dominance in science and technology that it enjoyed in the last half of the Twentieth Century. It can be a leading center of excellence of basic $R \& D$ if it invests more in $R \& D$ and makes science and engineering careers attractive to young Americans and to immigrant scientists and engineers.

\section{Why care?}

The calls for increased federal spending on basic science and related policies are motivated by economic and national security concerns. On the economic front, there is widespread belief that the US is more likely to maintain production and jobs in high tech sectors if the country pioneers scientific advances than if other countries pioneer those advances. The growth of high tech employment in Silicon Valley and in University-based locations of scientific excellence suggests that innovation, production, and employment in high tech occur largely in areas with excellence in science. ${ }^{5}$ Since leading edge industries have the fastest long run productivity growth, pay higher wages to production workers, ${ }^{6}$ and offer spillovers of knowledge to other sectors, there is global competition for these industries. Advocates of increased federal spending for basic R\&D also argue that the more basic R\&D performed in the US, the more likely is it that the country will attract industry in research-intensive sectors ${ }^{7}$.

Taking the argument a step further, many analysts note that the US's comparative

\footnotetext{
${ }^{4}$ U.S. R\&D increased by 6\% in 2006 according to NSF Projections (NSF, 07-317, April 2007 projected; 1990 from NSF, National Patterns of R\&D Resources, 1994, March 1995)

${ }^{5}$ Zucker, Darby and Brewer (1998) show that there are clusters of biotechnology activity around "star researchers" in nearby universities. Similarly, US states with greater supplies of university graduates have been in the forefront of the "new economy" (Progressive Policy Institute, 2002). For evidence on the impact of the aggregate impact of R\&D on productivity see Jones and Williams (2001) and Griliches (1998).

${ }^{6}$ Earnings of production and non supervisory workers in the three highly R\&D intensive sectors, aerospace, chemicals, and computers and electronic products averaged $\$ 20.00$ per hour compared to $\$ 15.97$ per hour for production and non supervisory workers in the country as a whole.

http://www.bls.gov/web/empsit.supp.toc.htm\#historical

${ }^{7}$ The idea that other parts of the value chain locate close to $R \& D$ is widespread. This may be much less true in today's more globalized world as the value chain can increasingly be disaggregated. For example, in pharmaceuticals drug discovery may be done in the US, but clinical trials may be located in Eastern Europe and drug manufacturing in India.
} 
advantage in global markets lies in high tech, research-intensive industries. Were the US to lose comparative advantage in those sectors, it would have to sell goods or services with lower technological content on the global market and compete with countries with similar technology and low wages. The gains from trade would lessen and wages would fall for American workers.

In terms of national security, proponents of increased US investment in science and engineering note that current "technologies for counter-terrorism and homeland security are outcomes of earlier US investments in science, technology, and education" (Jackson, 2003), and argue that science and technology offer the best defense against terrorist threats. The National Security Agency and various Defense Department laboratories and contractors hire only US citizens for critical research tasks, which make them particularly sensitive to the supply of citizens in the relevant fields. The scientist and engineering work force in security areas has become top heavy with older workers, which will create large replacement demands for citizen researchers.

\section{A more critical assessment}

Economic analysis provides some support for these arguments but also offers some caution about how much weight to place on them. For reasons of knowledge spillovers and economic competitiveness, investments in basic research can pay off in ways that justify major public investments ${ }^{8}$. But to determine whether the US is currently at, below, or above, the socially optimal level of public spending on basic research is not an easy task. In a global economy, where other countries are also investing in basic and applied research, and where major US-owned firms have become "global firms", it has become more difficult to assess the optimal level of public support for basic research than it was in the past.

\section{Knowledge spillovers}

Economists focus on knowledge externalities as the main reason for public spending on research. Because of the public good nature of knowledge, the benefits of research "spillover" to other agents and is only partially captured by the person or firm who originally invested in it. The result is that the private market will invest less in R\&D than is socially optimal, giving a strong rationale for government spending on R\&D in various ways. A large body of evidence shows that knowledge spillovers are statistically and economically significant ${ }^{9}$. Such spillovers are the foundation of modern growth theory (e.g. Aghion and Howitt, 1990; Romer, 1989).

While knowledge has always moved across international boundaries ${ }^{10}$, the spread of higher education and transfer of technology by multinational firms from advanced countries has made R\&D more international than ever before (Freeman, 2006). If knowledge spread instantly across boundaries, the rationale for government subsidies to research would decrease in favor of global subsidies ${ }^{11}$. In reality there is some

\footnotetext{
${ }^{8}$ There may be other market failure justifications, such as imperfections in financial markets.

${ }^{9}$ For a classic survey see Griliches (1992) and for more recent evidence see Bloom, Schankerman and Van Reenen (2006).

${ }^{10}$ See Keller (2004) for a survey and Griffith, Harrison and Van Reenen (2006) for recent evidence.

${ }^{11}$ More generally, the rationale for country support depends on the relative rate of diffusion of knowledge
} 
localization or "stickiness" to research so that the country or region within a country that does the research disproportionately benefits from the spillover. But modern communications such as the Internet and falling transport costs appears to have reduced this advantage (Griffith, Lee and Van Reenen, 2007), weakening the spillover justification for R\&D subsidies. By a similar logic, the growth of an international labor market for scientists has meant that many US universities attract PostDocs and faculty from the international market, reducing the necessity of using US taxpayers' money to train the next generation of scientists and engineers.

\section{Economic "Competitiveness"}

Firms compete in the marketplace: when one firm does better it is often at the expense of other firms. Countries do not "compete" in the same sense. While there are situations in which one country's gain is another country's loss (e.g. Baumol and Gomory, 2004) the benefits of R\&D-induced or other innovations that improve productivity in once country are likely to flow to persons in other countries as well. Given the public goods nature of R\&D and trade in goods and services, the expansion of modern scientific and technological activity in the world should improve the lives of people worldwide regardless of the location of the innovative activity. If a medical scientist in China, India, the UK, or anywhere else finds a cure for cancer, we will all benefit. If a German innovation lowers the price of household goods and services, we will all benefit. If scientific advances and innovations overseas lead foreign firms to set up production facilities in the US or if US firms exploit overseas innovations to produce in the US this will create jobs as well as better products.

At the same time, countries can use publicly funded R\&D to boost their country's strategic position in some sectors, potentially creating comparative advantage that would not exist absent the public support (e.g. in the commercial airline market). Strategic trade theory has models in which R\&D subsidies can help countries attract and retain rentgenerating R\&D intensive sectors (e.g. Brander and Spencer, 1985) ${ }^{12}$. At the same time, the fall of transportation costs and entry barriers makes multinational R\&D more internationally mobile. For example, "footloose" R\&D may be able to move more quickly to jurisdictions offering a more favorable tax regime for R\&D (see Wilson, 2008, for evidence of this in the US context). By making it easier to attract R\&D, this sharpens the case for subsidizing science on economic competitiveness grounds.

These arguments are summarized in Table 2. In our view, knowledge spillovers are the strongest argument for $\mathrm{R} \& \mathrm{D}$ subsidies, especially for basic research compared to applied research. Nonetheless, globalization has probably weakened the case for such subsidies whereas it has strengthened the case for subsidies to applied research. There are two caveats to this assessment. First, if basic research is complementary to applied research, then subsidies to basic research could "crowd in" more applied research. There is evidence on this from the positive local effects of university research (e.g. Jaffe, 1989).

within a country and across countries. If diffusion rates increase proportionately the social vs. private margin for national investments would be stable.

${ }^{12}$ Convincing empirical evidence of the quantitative importance of these strategic R\&D competitions is rare. Those that have studied it generally find that the strategic R\&D competition effect is dwarfed by the knowledge spillovers effect (e.g. Bloom, Schankerman, Van Reenen, 2006). 
But at some point basic and applied research are substitutes - in terms of Federal subsidies for example, spending more on one means cutting back funding on the other. Second, the normative argument for strategic R\&D subsidies is weakened by the fact that other countries may respond to US subsidies with their own subsidies. When countries compete in subsidizing $R \& D$ to attract high tech firms, it is like an auction for multinational R\&D. The main winners of this auction are likely to be multinational companies and their shareholders rather than taxpayers.

\section{The US position in innovation}

While the US share of world R\&D and the scientific and engineering work force has fallen as other countries have invested higher education and research, the US remains the world leader in scientific and technological competence. The US spends more on R\&D in total dollars and has more scientists and engineers doing research, basic and applied, than any other country. The ratio of R\&D to GDP in the US is higher than in other major advanced countries, save for Japan (NSF, 2008, Appendix table 4-35). Despite the EU's "Lisbon Agenda" push to raise the R\&D/GDP ratio to $3 \%$, the large countries in the European Union continue to fall far short of the US's level of 2.6\% in 2005.

European countries have increased government investment in R\&D relative to GDP but European firms invest a much smaller share of revenues on R\&D than do US firms, who have raised their R\&D budgets even as the federal government has invested less. Figure 1 shows the position of R\&D performed by business as a proportion of GDP in several major countries since 1981. The US business R\&D to GDP ratio has remained broadly stable, rising modestly from 1991 (1.5\%) to 2006 (1.7\%). It exceeds all the other major nations bar Japan. Chinese business R\&D has come, by contrast, from nowhere in the 1980 s to over $1 \%$ of GDP today. This illustrates both the remarkable catch-up by China and the fact that China remains less R\&D intensive than the US.

How has the US done in the R\&D intensive high tech industries? Table 3 shows that from 1980 through 2003 the US did well by several measures of innovativeness and production in high tech. The share of USPTO patent applications going to first-named US persons remained roughly constant from 1985 to 2005 while the share of European Patent Office applications going to first-named US persons fell only slightly. In high-tech manufacturing ${ }^{13}$ the US share of world gross revenue and of value added rose during the 1990s boom and remained high through the early 2000s. In the global economy where firms outsource parts of activities to different places in the world, the most meaningful measure of US economic activity relative to other countries is value added. The US share of world value added in high tech rose from $25 \%$ in 1990 to $42 \%$ in 2003.

Where US performance has been less impressive is in the balance of trade. In 1980 and 1990 the US ran a large balance of trade surplus in high tech, which partially counterbalanced the country's trade deficit in other goods. The trade balance in high tech turned negative in 2000 and has gone more negative since, along with the rest of the country's balance of trade (Weller and Wheeler, 2008) .

Since patents and production depend on past scientific advances, it is possible that the positive picture of US performance in high tech scientific-intensive sectors shown in

\footnotetext{
${ }^{13}$ This is defined by the OECD to include aerospace, communications equipment, office machinery and computers, pharmaceuticals, and scientific instruments
} 
table 3 reflects the advantages of US investments in R\&D in past years. From this perspective, the call for increased federal R\&D spending and the investment in science and engineering worker is more of a pre-emptive warning than a response to any economic disaster. Given that research is exploration of the unknown with payoffs in the future, this is arguably the appropriate way to interpret the competitiveness initiative and plethora of calls for additional R\&D spending.

\section{THE NIH DOUBLING Background}

To see how a potential future rapid increase in R\&D spending on the physical sciences might affect researchers, we examine the 1998-2003 doubling of the NIH research budget and the subsequent deceleration of $\mathrm{NIH}$ funds. ${ }^{14}$ Figure 2 displays the level and percentage change in NIH funds from 1995 through 2007. From 1998 to 2003 the NIH budget grew by double-digit amounts in nominal terms, which raised annual $\mathrm{NIH}$ spending from about $\$ 14$ billion to $\$ 27$ billion. In constant CPI dollars real research funding increased by $76 \%$. In the decade prior to the doubling (1987 to 1997), real NIH funding deflated by the CPI increased by only $40 \%$ (NSF, 2004, Table $1 \mathrm{H}$ ). Thus the doubling raised NIH spending by twice as much in five years as it had done in the previous decade. Using the Biomedical R\&D Price Index (BRDPI), which rose more rapidly than the CPI, the doubling increased spending by $66 \%$.

When the doubling ended, the Bush Administration recommended a rapid deceleration in NIH funding, which Congress largely followed. The rate of increase in spending dropped in nominal terms to $3 \%$ in 2004 , then to $2.2 \%$ in 2005 , to $-0.1 \%$ in 2006 and to $0 \%$ in 2007 . Using the CPI deflator, real NIH spending was $6.6 \%$ lower in 2007 than in 2004; it is expected to fall 13.4\% below the 2004 peak by 2009 (Garrison and McGuire, 2008). Using the BRDPI deflator, real spending was down $10.9 \%$ through 2007. The drop in the real NIH budget shocked the agency and the bioscience community as it undid much of the extraordinary increase in funding from the doubling. NIH director Elias Zerhouni said that even in "the worse scenario, people really didn't think that the NIH budget would go below inflation" (Couzin and Miller, 2007). NIH responded first by reducing the number of grants awarded, and then by reducing the amounts of grants. For the post doctorate researchers trained during the doubling period and for the young researchers who obtained their first independent research grants during the doubling, the deceleration created a career crisis. For principal investigators (PI's) with NIH support, it also posed major problems, as the probability of continuing a grant and making a successful new application fell and as the size of grants shrunk. Research labs were pressured to cut staff. At NIH, which is the single largest employer of bio-

14 The experience of the NIH doubling is more relevant to a future increase in R\&D than the doubling of federal $R \& D$ spending following the Sputnik. In that period the supply of S\&E workers was primarily domestic, so that the increase raised salaries greatly, inducing more native students to enter the field and increase supply in the future (Freeman, 1975). Today, with the international market in science and engineering workers, supply is more elastic so that increased spending will likely have a greater impact on quantities than wages. 
medical researchers in the country, with over 1,000 principal investigators and 6,0007,000 mostly $\mathrm{PhD}$ researchers the reduced funding led to a contraction in the number principal investigators by $9 \%$. "A completely new category of nightmare" was the description given by a researcher in the National Institute of Child Health and Development, which was especially hard hit (Science, March 7, 2008, p 1324). Others in the scientific and university community also reacted with dismay or horror. Typical examples are:

"The marvellous engine of American biomedical research that was constructed during the last half of the 20th century is being taken apart, piece by piece." -- Robert Weinberg (founder of Whitehead Institute) Cell, July, 2006.

"Without effective national policies to recruit young scientists to the field, and support their research over the long term, in 10 to 15 years, we'll have more scientists older than 65 than those younger than 35. This is not a sustainable trend in biomedical research and must be addressed aggressively."-- NIH Director Zerhouni.

Most of the scientific community views the doubling as having significantly increased the rate of bio-medical knowledge creation above what it otherwise would have been. But the effects of the doubling may have been muted due to the adjustment costs associated with such a rapid increase (see below). If, moreover, labor supply is inelastic, the increase in funding will show up in the short ruin in higher wages for scientists' rather than an increase in research (Goolsbee 1998), though in long run the higher wages will presumably attract more talent into science. Given the international mobility of scientists, moreover, increased spending is more likely to prompt migration into the US of overseas scientists and post docs than in the past.

Still, it is hard to find clear evidence that the doubling raised scientific output. Sachs (2007) noted that the number of bio-medical publications from US labs grew at a steady rate after 1999. The share of US S\&E articles in the biological and medical sciences from 1995 to 2005 (NSF, 2007, Appendix table 5-36) did not tilt toward these areas despite their increased share of the nation's basic research budget. Using a regression discontinuity design that compared the publications of scientists who just succeeded in obtaining an NIH grant with those who just failed to obtain a grant in the period 1980 to 2000, Jacob and Lefgren (2007) found only a small impact of receiving an $\mathrm{NIH}$ grant on research output, though one that is larger for younger than for older scientists. To be sure, without a well-specified counterfactual of what would have happened absent the doubling or with some adjustment in the numbers of articles for their quality, we cannot rule out the possibility that the funding in fact spurred more and better science. Still, the data are consistent with the notion that by increasing spending quickly in a short period, NIH did less to increase scientific production than it might have done if it had increased spending more evenly over time.

Our analysis highlights two problems with the NIH pattern of increasing R\&D spending: the frontloading of the increase in a short period of time; and the allocation of the increase between the size and number of grants and between younger and older researchers. We consider the economics of each problem in turn.

\section{Big Push vs. Gradual Change}

In general, a rapid acceleration in spending followed by a rapid deceleration is an 
inefficient way to get to a permanently higher level of research activity and stock of research scientists. To see why this is so we apply the classic accelerator model of investment in physical capital to increasing $\mathrm{R} \& \mathrm{D}$. We treat the stock of research by the "perpetual inventory formula" $K_{t}=I_{t}+(1-\delta) K_{t-1}$, where $K$ is the number of scientists engaged in research; $I$ is the number of newly trained scientists (Post Docs) who enter into research and $\delta$ is the proportion of scientists who leave research each year for retirement or other reasons. In this model $K_{t}$ is the stock of activity in year $t, I_{t}$ is the flow of new activity and $\delta$ is the depreciation rate. $K$ and $I$ are related to the number of trained scientists or new scientists by a fraction $\theta$, which measures the proportion that work in academia doing basic research. The rest are engaged in other activities - working in industry, government - or teaching, doing administration, and so on.

In the accelerator model of investment, an increase in the demand for output induces firms to seek a higher capital stock to meet the new demand. This increases investment spending quickly. When firms reach the desired capital stock, they reduce the rate of investment sharply. Analysts of business cycles have long used this model to explain the greater volatility of investment than of consumption spending that contributes to cyclical fluctuations in the economy. In the case of basic R\&D, assume that society wants to increase the stock of research activity from $K^{O L D}$ to a new desired level of $K^{N E W}$. The goal is to increase the stock of research activity, not to "double" or otherwise increase the flow of spending. While it may attract public or political support by making the increase in spending the goal, it is the sustainable stock of research activity that presumably contributes to national output.

The optimal path to attaining a higher stock depends on the costs of adjustment, which will include such things as disruptions to labs, hiring new staff, buying new equipment, and so on. Most empirical studies find evidence that adjustment costs for $\mathrm{R} \& \mathrm{D}$ are substantial compared to other forms of investment ${ }^{15}$. We assume that the costs rise more than proportionately with the size of the change in any period. Building one new R\&D lab involves disruption; building five new labs at the same time is likely to be more than five times as disruptive ${ }^{16}$. Many models of adjustment use a quadratic cost curve to measure this more than proportionate rise in cost. If adjustment costs take any convex form of this type the ideal adjustment path is a slow incremental movement to the new desired level. This would mean increasing R\&D incrementally to reach $K^{N E W}$ rather than increasing it in a sudden burst.

Figure 3 shows the difference between the optimal relatively smooth adjustment to the new level of $K$ and adjustment that more closely mirrors the NIH doubling. At the start of the period investment is just equal to the depreciated old capital (e.g. new Post Doc flow exactly balances the retiring older scientists so $\left.I_{t}=\delta K_{t-1}\right)$. The dotted line of circles shows the ideal increase to the new level $K^{N E W}$. The line of triangles is closer to what actually happened. The area in between determines the inefficiency of the system. The inefficiency means that society could have greater total $R \& D$ activity in the long run if it increased spending more gradually. With quadratic adjustment costs, the inefficiency

\footnotetext{
${ }^{15}$ Hall (1992), Himmelberg and Peterson (1994) or Bond and Van Reenen (2008).

${ }^{16}$ Adjustment costs come in many forms. They include building new R\&D labs, recruiting and training new staff and system wide adjustment costs that we discuss shortly.
} 
can be substantial ${ }^{17}$.

The way bio-medical research works, with senior scientists running labs in which Post Doctorates and graduate students perform most of the hands-on work, much of the adjustment costs fall onto young researchers. An increase in R\&D increases the number of Post Docs hired and the number of graduate students that principal investigators seek to attract to their labs. Paralleling the rapid rise of investment when demand for output rises in the accelerator model of physical capital, the number of Post Docs/graduate student researchers grows sharply with increased R\&D. The benefits or costs of the adjustment fall disproportionately on the new entrants into the market. On the benefit side, increases in demand should raise the pay and job opportunities more for new graduates than for older scientists. On the cost side, young persons trained during an upsurge in spending will compete with a larger supply of young biomedical researchers after the upsurge, when there are likely to be no greater or even fewer independent research opportunities than when they were attracted to the field.

Part A of Figure 4 shows that during the doubling period the number of Post Docs increased rapidly while the number of principal investigators barely changed. Part B of the figure shows that much of the increase in Post Docs during the doubling period came from foreign-born PhDs, of whom about half were trained outside the US.

Even before the doubling there was a sizable increase in the number of post-docs in the US. The number of postdocs began increasing rapidly in the early 1980s (Garrison and McGuire, 2007,slide 28), producing a major imbalance between the number working in academic labs and the number of tenure-track academic jobs to which they could aspire. In 1987 the ratio of Post Docs to tenured faculty in the life sciences was 0.54 - or approximately one Post Doc for every two faculty. By 1999, the ratio of Post Docs to tenured faculty had risen to 0.77 . The situation did not change much in the doubling period. The number of full-time senior faculty in the life sciences grew by $13 \%$ (NSF, 2008, appendix table 5-19) while the number of Post Docs in biological sciences grew by $18 \%$ (NSF, 2006, table 49). In the 1970s about three quarters of Post Docs obtained academic jobs, but no more than $20 \%$ to $30 \%$ of the increased number in the 2000 s can expect positions in academic research. The vast bulk of Post Docs will end up in nonacademic research jobs. The slowdown of NIH spending after the doubling led to effectively no growth for either senior faculty or Post Docs.

In sum, the rapid acceleration and deceleration of NIH spending created problems for researchers and potential researchers. In considering any future increases in federal support for basic research, policy-makers should focus on attaining a socially desirable sustainable rate of scientific activity relative to GDP rather than on increasing the rate of spending over a short period. The optimal policy is to move slowly to the desired level of $\mathrm{R} \& \mathrm{D}$, minimizing as far as possible adjustment costs, rather than following a "feast then

\footnotetext{
${ }^{17}$ If R\&D spending were mainly an irreversible fixed cost then the optimal adjustment path in Figure 3 would not be smooth adjustment, but rather a sudden shift closer to the actual change. This is unlikely to be a good description of adjustment costs however, especially at the aggregate level. Also note that our analysis assumes ignores any possible advantage to producing new research earlier than later beyond the standard discounting of future benefits -- for instance through spillovers over time that improve the productivity of future research. If there are such gains, they must eventually suffer from diminishing returns so that rising adjustment costs dominate the calculation on the margin where the decision about funding is made.
} 
famine" spending policy. We offer some suggestions as to how to do this in a world where Congress sets budgets annually in our conclusion.

\section{Internal organization of bio-medical research}

At the heart of the American bio-medical science enterprise are the R01 grants that NIH gives to fund individual scientists and their teams of Post Doctorate employees and graduate students. The system of funding individual researchers on the basis of unsolicited applications for research support comes close enough to economist's views of how a decentralized market mechanism operates to suggest this ought to be an efficient way to conduct research compared, say, to some central planner mandating research topics. The individual researchers choose the most promising line of research based on "local knowledge" of their special field. They submit proposals to funding agencies, where panels of experts - "study sections" in the NIH world - give independent peer review, ranking proposals in accordance with criteria set out by funding agencies and their perceived quality. Finally, the agency funds as many proposals with high rankings that it can within its budget constraint.

On the funding side, there is also competition. There are non-government funders such as the Howard Hughes Foundation, a major supporter of independent researchers, and many medical foundations focused on particular diseases or issues, as well as NSF and other government agencies. NIH itself, moreover, is a diverse institution with a variety of programs, institutes, and centers that make their own research support decisions. With many groups seeking to support research and many scientists seeking support for their research, the level of competition would seem to be sufficiently broad and wide to yield good economic outcomes.

Still, in the market for bio-medical research, NIH is the 800-pound gorilla. For most academic bio-scientists winning an NIH R01 grant is critical to their research careers. It gives young scientists the opportunity to run their own lab rather than to work in the lab of a senior researcher or to have to abandon research entirely. For scientists who have an NIH grant, winning a continuation grant is often an implicit criterion for obtaining tenure at a research university.

Table 4 provides a statistical overview of the RO1 granting process from 1980, when it was relatively easy for bio-medical scientists to obtain grant support, through the 1998-2003 doubling period and through 2007. It presents data for two groups of applicants for research awards. The first group consists of "potential new awardees" -researchers who had not previously applied for an NIH grant. ${ }^{18}$ Because Post Docs rarely apply for the RO1s, potential first time awardees are primarily newly hired assistant professors in research universities. ${ }^{19}$ The second group consists of experienced

\footnotetext{
${ }^{18}$ Applicants are considered new investigators if they have not previously served as the principal investigators (PI) on any Public Health Service-supported research project other than a small grant (R03), an Academic Research Enhancement Award (R15), an exploratory/developmental grant (R21), or certain research career awards directed principally to physicians, dentists, or veterinarians at the beginning of their research career (K01, K08, and K12). Current or past recipients of Independent Scientist and other non mentored career awards (K02, K04) are not considered new investigators

${ }^{19}$ While NIIH has no restriction against post-docs applying for research grants, its website states that: "before you seek an independent research grant, you should hold a Ph.D. or M.D; Have a faculty-level position, usually assistant professor or higher; Have a publication record in the field in which you are
} 
researchers, those who had previously been funded by NIH. They may be applying for a continuation grant or possibly a new grant to undertake a project that differs from what they had been working on.

In 1980 the agency received more applications from potential new awardees than from experienced researchers but gave more awards to previous awardees than to new investigators. It funded $44 \%$ of experienced applications vs. $22 \%$ of applications from new investigators. As the stock of researchers increased in the 1980s and 1990s, the number of submissions from previous awardees increased. By 1998 the agency had fewer submissions and gave fewer awards to new researchers than in 1980, while it had more submissions and gave more grants to experienced researchers.

During the doubling period, the number of applications from both potential new awardees and experienced researchers increased significantly and NIH gave more grants to both. The deceleration in the funding of NIH produced a sizable drop in number of grants awarded from 2003 to 2006 even as the number of submissions increased, with again the percentage changes being larger for the potential awardees. In $2006 \mathrm{NIH}$ trimmed the amounts it gave for continuing grants by $2.35 \%$ despite inflation, and used the funds saved to increase the number of grants to new researchers, though the number of awards still remained below the number in 2003. It did this in an effort to keep new researchers with high quality proposals in research activity.

The lines in Table 4 referring to success rates of potential first time awardees with their original proposal or with a first amendment shows another change in the research process: a marked drop in the percentage of applicants who gain a grant with their original submission ${ }^{20}$. In $198055 \%$ of awardees obtained support on the first submission compared to $28 \%$ of awardees in 2007 . Increasingly, researchers gain awards after amending the submission to meet with objections or suggestions of the panel that reviewed their proposal. The sum of the percentages for success with the original proposal and the first amendment also drop over time, implying that NIH asked for second or third submissions before giving a grant. This means that projects were delayed for perhaps a year.

While it is common to refer to new RO1 awardees as "young researchers" the term is a misnomer. Because R01s generally go to scientists who are assistant professors or higher in their rank, and the length of post doctorate jobs has grown over time, the average age of a new recipient was 42.9 in 2005 up from 35.2 in 1970 and 37.3 in the mid 1980s. Figure 5 shows that in $198022 \%$ of grants went to scientists 35 and younger, but the proportion trended downward so that in 2005 , just $3 \%$ of grants went to scientists 35 and younger. By contrast, the proportion of grants going to scientists 45 and older increased from $22 \%$ to $77 \%$ of R01s. Within the 45 and older group, the largest gainers were scientists aged 55 and older.

Part of this change is associated with an aging of the science work force, but most

applying; Work in a research institution that will provide the resources, e.g., equipment and lab space, you will need to complete the project." http://www.niaid.nih.gov/ncn/grants/new/new06.htm “ In addition, You will also need preliminary data for an R01." Universities have general rules guiding the level of investigator that may apply for independent funding and about the resources they will provide to help in the grant process.

${ }^{20}$ Much like journals, study groups can choose to accept or reject new submissions outright or ask for a revision of the original submission. 
of it is due to the changing organization of research, which gives older investigators substantive advantages in obtaining funding and places younger researchers as Post Docs in their labs. Taking account of the distribution of $\mathrm{PhD}$ bio-scientists by age, the relative odds of a younger scientist gaining an NIH grant compared to someone 45 and older dropped over tenfold. We do not attribute this pattern to the doubling of research moneys, as it reflects a longer run trend. But we note that NIH did not use the extra moneys to improve career prospects for graduate students or Post Docs. The result is considerable malaise among graduate students and Post Docs in the life sciences as well as among senior scientists concerned with the health of their field. (NRC, 1998; NAS, 2005; American Academy of Arts and Sciences, 2008).

\section{Research grants for younger scientists?}

Should the country be concerned about the small declining share of grant moneys that goes to younger scientists and to the increased number of years that it takes them to obtain independent research support? In terms of economic analysis, there are three reasons for believing that the concentration of research support on older scientists has deleterious effects on research productivity.

The first is the possibility that scientists are more creative and productive at younger ages. To the extent that younger scientists are more likely to undertake breakthrough research when they have their own grant support rather than when they work as Post Docs in the labs of senior investigators and are more likely to undertake such work than older scientists, concentrating research support on the older group reduces the productivity of research and the payoff from government funding. ${ }^{21}$

The second reason is that supporting scientists earlier in their careers will increase the pecuniary attractiveness of science and engineering to young persons choosing their life's work. It will do this because the normal discounting of future returns makes money and opportunities received earlier more valuable than money and opportunities received later. If students who consider science careers had a better chance to become independent investigators in their thirties rather than in their forties or fifties, we would expect the number who chose science to be higher than it is today. ${ }^{22}$

The third reason relates to the likely use of new knowledge uncovered by researchers. A research project creates two outputs. It produces research findings that are public information. But it also increases the human capital of the researcher, who knows better than anyone else the new outcomes and who probably has better ideas of how to apply them to future research or other activities than other persons. Assume that an older researcher and a younger researcher are equally productive and accrue the same additional knowledge and skills from a research project. Then because the younger person will have more years to use the new knowledge, the social payoff from funding the younger person will be higher than from funding the older person. Just as human

\footnotetext{
${ }^{21}$ There have been some analyses of the relation between age and scientific productivity. See Jones (2005) and the literature cited therein. But there is no analysis of whether working in someone else's lab affects productivity.

${ }_{22}$ Freeman (2005) and Freeman, Chang and Chiang (2005) show substantial responsiveness of young persons to NSF Graduate Research Fellowships. It is hard to imagine if they offered $\$ 30,000$ awards 20 years into the future, they would apply to the Fellowships as much as they have.
} 
capital theory says that people should invest in education when they are younger, because they have more years to reap the returns than if they invested when they are older, this line of thinking implies that it would be better to award research grants to younger scientists than to otherwise comparable older scientists.

In sum, economic analysis lends some support to the views of the scientific community that society would likely get more "bang for its research buck" if the internal structure of research funding was more favorable to younger researchers than it is.

\section{FUNDING AGENCY AND RESEARCHER BEHAVIOR}

Funding agencies and researchers interact in the market for research grants. An agency with a given budget must decide how to allocate the budget between the number of grants and the sizes of grants, presumably with the goal of maximizing research output. Should it give fewer large grants or more small grants? Should it favor new research submissions, whether from younger or experienced researchers, or continuance of existing grants from experienced researchers? The effect of these decisions on research output depends in turn on how do researchers respond to changes in the dollar value and number of potential research awards.

Table 5 shows that during the doubling, NIH increased the average value and number of awards, particularly for new submissions (which includes new projects proposed by experienced researchers as well as projects by new investigators). With the success rate of awards stable at roughly $25 \%$-- a proportion that the agency views as desirable to support on the basis of the quality of proposals, -- the number of awards increased proportionate to the number of submissions.

From 2003 to 2006 when the budget contracted in real terms, NIH maintained the value of awards in real terms, and reduced the number of new awards by $20 \%$. With the number of new submissions growing, the result was a large drop in the success rate. In 2007, NIH squeezed the budgets of existing projects and raised the number of new awards. The data on continuation grants for existing projects shows a similar pattern increases in the number and amount awarded during the period of doubling and reductions in numbers awarded relative to submissions afterwards.

Although its budget increased more modestly in the early and mid 2000s, NSF faced similar decisions regarding the allocation of budgets between the number and average size of awards (amount per year and duration) and between new and previously funded investigators. Responding to a 2001 Office of Management and Budget concern that NSF researchers spent too much time writing grant proposals instead of doing research, NSF decided to increase the amount of research awards while holding fixed or reducing the number of awards. Giving larger grants to a smaller proportion of researchers would, in NSF's eyes "minimize the time PIs would spend writing multiple proposals and managing administrative tasks, providing increased stability for supporting graduate students" (IPAMM, 2007, p5). Table 6 shows that, consistent with this, NSF increased the mean dollar value of awards from 1997 to 2006 by $72 \%$ (from $\$ 78,223$ to $\$ 134,595$ ) compared to a $13 \%$ increase in the number of awards. The number of research proposals grew rapidly over the period, presumably in part due to the increased dollar value of awards, but also possibly because of the greater ease of submitting proposals through the NSF's fast track system. In any case, the success rate for funding dropped 
from $30 \%$ to $21 \%$, which our analysis suggests would spur additional applications. In 2006 , NSF funded $62 \%$ of highly rated proposals whereas in 1997 it had funded $76 \%$ of such proposals. Proposals that were highly rated but ultimately declined represented $\$ 2$ billion in requested research support in 2006 (IPAMM, 2007).

How did researchers respond to these changes in the allocation of funds between amounts and numbers? What can we learn from those responses to guide agency decisions about the division of any future large increase in R\&D spending and the inevitable ensuing deceleration in the rate of spending?

Researchers responded to the NIH doubling by submitting more proposals to the agency. While NSF spending increased more modestly in the late 1990s early 2000s, NSF saw an increase in proposals as well. Given higher grant awards and increased numbers of awards (with roughly constant funding rates), the growth of submissions reflects standard economic supply behavior: positive responses to the incentive of more and higher valued research awards. What about responses to declines in research support? If researchers submitted a single proposal to agencies, we would expect reduced numbers or sizes of awards that lower the expected value of a submission to lead them to make fewer submissions. But the fact that researchers can submit more than one proposal to funding agencies alters their potential supply behavior, at least in the short run. Some researchers could submit more proposals in periods of low numbers of awards in the hope of improving the chance they will gain at least one award and thus be able to continue their research work.

Table 5 shows that this is what happened in NIH after the doubling period. The average number of submissions per new award granted and per continuation awards granted rose sharply from 2003 to 2007 after changing only modestly during the doubling period. By $2007 \mathrm{NIH}$ awardees were putting in roughly two proposals to get an award. Data on the proportion winning awards on an original proposal in the table tells a similar story: fewer investigators gaining awards on original proposals, inducing them to amend proposals in response to peer review reports to increase their chances of gaining a research grant.

The data for NSF in table 6 tells a similar story. The number of research proposals submitted per PI before receiving one award increased by 1.7 in 1998-2000 to 2.2 in 2004-2006. The statistics underlying the averages in the table show that the proportion of PI awardees making a single submission dropped from 59\% to $51 \%$ while the proportion of PI's making three or more submissions increased from $18 \%$ to $26 \%$. The notion that by giving fewer large grants NSF would reduce the time spent writing multiple rewards turned out to be largely wrong. Faced with the risk of losing support and closing or contracting their labs, PIs made multiple submissions.

In Appendix B we present a simple model of researcher behavior consistent with this form of behavior. The model gives researchers the option of submitting 0,1 or 2 proposals to a funding agency. We assume that each researcher wants only a single grant to conduct their work. In this situation, the very best researchers submit one application (since they are virtually assured of getting support), but some researchers choose to submit 2 proposals because they judge their chances of winning as lower but still above the costs of developing a proposal. A third group decides against making a proposal. When the value of awards increases, a larger proportion of scientists make bids and a 
larger number make two bids, and conversely when the value of awards decreases. The interesting behavior occurs when the number of awards granted changes. An increase in the number of awards increases the number of researchers who apply as the chances of winning increases. But when the number of awards decreases, the model says that it is likely that a larger proportion of applicants will put in two bids. Some highly able scientists make additional proposals because they are uncertain that they will gain an award and maintain their lab. The result is an increase in the average number of proposals from researchers who ultimately gain an award, and a research grant process that consumes a larger fraction of researchers' time. In addition, the increased proportion of potential grantees writing multiple grants means that they have less time to peerreview the proposals of their colleagues. This puts a strain on the whole system.

It is possible that this process by itself discourages some young persons from going on in science. Who wants to spend time writing proposal after proposal with modest probabilities of success? It may also lead to more conservative science, as researchers shy away from the big research questions in favor manageable topics that fit with prevailing fashion and gain support from study groups.

While our analysis deals with only some of the decisions facing research granting agencies and researchers, it highlights makes a key point about the research process: that funding agencies need good knowledge of the likely behavior of researchers to allocations of funds in order to get the most research from their budgets. Conceptually, there is an optimal division of budgets between numbers and values of awards and between new and continuing grantees that depends on the response of researchers. From NIH experience with the doubling and ensuing cutback in funds and NSF experience with increasing the size of awards while barely changing the numbers, the agencies have presumably learned enough about researcher behavior that they would respond differently to future increases in R\&D budgets than they have in the past.

\section{CONCLUSIONS}

This study directs attention at how policy-makers might best undertake any future sizable increase in R\&D spending, of the type envisaged for the physical sciences by the American Competitiveness Initiative.

We have noted that globalization affects traditional justifications for government funding of R\&D as a public good. Increasing spillovers of knowledge across national borders reduces the ability of any country to recoup the benefits of basic $R \& D$, and thus weakens the public goods argument for greater US spending. But at the same time, the greater international mobility of high tech research-intensive industries that are drawn by strong basic research in an area argues for larger support of basic R\&D than in the past. We have made no effort to quantify these two effects.

Our analysis stresses that future increases in research spending should be seen in terms of increasing the stock of sustainable activity rather than in attaining some arbitrary target (ie doubling) in a short period. There are virtues to a smooth approach to higher (or lower) levels of spending, which are particularly important for R\&D, as distinct from most other forms of investment, because it takes considerable time to build up human capital, which then has a potentially long period of return. Since Congress determines budgets annually, the question becomes how either the Congress can commit to a more 
stable spending goal or how agencies and universities can offset large changes in funding from budget to budget.

We have two suggestions here. The first would be for research grants to contain an extra "stabilization" overhead with the stipulation that universities or other research institutions place those payments into a stabilization fund to provide bridge support for researchers when R\&D spending levels off. The second is to assign some of the R\&D tax credits that boost applied research to a basic research fund that would provide smooth funding for basic research. There is considerable evidence that fiscal incentives for R\&D impact on firm's R\&D behavior ${ }^{23}$. Whether it is better to support applied research through tax breaks or basic research through grants will depend on how much is spent on each.

Third, our analysis highlights the importance of funding agency decisions about the division of research budgets between younger and older researchers, and between numbers of awards and sizes of awards. Because younger investigators have longer careers than equally competent older investigators over which to use the newly created knowledge, we have argued that that there is good reason to tilt any future surge in spending toward younger scientists. In addition, given multiple applications and the overstretch of the peer review system, it might increase efficiency for agencies to add program officers and find ways to deal more efficaciously with proposals, as indeed both NIH and NSF have begun to do.

In sum, if there is to be a new surge in research budgets, there are pitfalls to avoid from the NIH doubling experience, and different ways agencies could allocate funds that might get more research output for the dollars spent. Additional research funding spent more efficaciously could attract and retain the young scientists on whom future progress depends and improve the flow of the new science that can help the US economy and contribute to the solution of the diverse problems that threaten global well-being.

\footnotetext{
${ }^{23}$ See Bloom, Griffith and Van Reenen (2002) for international evidence or Hall and Van Reenen (2001) for a survey focusing on US evidence.
} 


\section{References}

Aghion, Philippe and Howitt, Peter (1990) "A model of growth through creative destruction" Econometrica, 60, pp.323-51

American Academy of the Arts and Sciences (2008) Alternative Models for the Federal Funding of Science Committee Report

Baumol, William and Gomory, Ralph (2004) Global Trade and Conflicting National Interests, Cambridge: MIT Press

Bloom, Nick, Schankerman, Mark and Van Reenen, John (2006) "Technology Spillovers and Product Market rivalry" Centre for Economic Performance Discussion Paper No. 675.

Bloom, Nick, Griffith, Rachel and Van Reenen, John (2002) "Do R\&D Tax Credits Work?" Journal of Public Economics (2002) 85 1-31

Bond, Stephen and Van Reenen, John (2008) "Micro-econometric models of investment and employment" in Handbook of Econometrics Volume VIB edited by Jim Heckman and Ed Leamer.

Brander, Jim and Spencer, Barbara (1985) "Export subsidies and international market share rivalry" Journal of International Economics 18, 83-100

Couzin, Jennifer and Miller, Greg (2007) "NIH Budget: Boom and Bust" Science 20 (316), 5823, pp. 356 - 361

Domestic Policy Council Office of Science and Technology Policy February 2006 http://www.nist.gov/director/reports/ACIBooklet.pdf

Freeman, Richard (1975) "Supply and Salary Adjustments to the Changing Science Manpower Market: Physics, 1948-1973”, American Economic Review, March

Freeman, Richard (2005) "Fellowship Stipend Support and the Supply of Scientific/Engineering Students: NSF Graduate Research Fellowships" American Economic Review, May

Freeman, Richard, Tanwin Chang, and Hanley Chiang (2005) "Supporting the Best and Brightest" NBER Working Paper No. 11623

Freeman, Richard (2006) "Does Globalization of the Scientific/Engineering Workforce Threaten U.S. Economic Leadership?” Innovation Policy and the Economy (volume 6, edited by Adam Jaffe, Josh Lerner, and Scott Stern) NBER 
Freeman Richard (2008) "What Does Growth of Higher Education Overseas Mean to the US?” forthcoming NBER conference on Higher Education (Charles Clotfelter, editor)

Garrison, Howard and Kimberly McGuire, (2007) "Employment of Biological and Medical Scientists,'FASEB www.opa.faseb.org/pdf/Training\%20Presentation\%202007.ppt

Garrison, Howard and Kimberly McGuire (2008), "NIH Research Funding Trends, FY1995-2009,'FASEB http://opa.faseb.org/pages/PolicyIssues/nihfundingtrends_ppt.htm

Goolsbee, Austan (1998) "Does government R\&D policy mainly benefit scientists and engineers?” American Economic Review, 88(2), 298-302

Griffith, Rachel, Harrison, Rupert and Van Reenen, John (2006) "How special is the special relationship? Using the impact of US R\&D spillovers on British firms as a test of technology sourcing" American Economic Review, 96(5) 1859-1875

Griffith, Rachel, Lee, Simon and Van Reenen, John (2006) "Is distance dying at last? Falling Home bias in fixed effects models of patent citations" Centre for Economic Performance Discussion Paper No. 818

Griliches, Zvi (1992) "The search for R\&D spillovers" Scandinavian Journal of Economics

Griliches, Zvi. (1998) $R \& D$ and Productivity: The Econometric Evidence (Chicago: University of Chicago Press)

Hall, Bronwyn H. (1992), "Investment and research and development at the firm level: does the source of financing matter?", Working Paper no. 92-194, Department of Economics, University of California, Berkeley.

Hall, Bronwyn H. 1993. "R\&D Tax Policy during the Eighties: Success or Failure?" Tax Policy and the Economy 7 (1993): 1-36.

Hall, Bronwyn H. and Van Reenen, John (2001) "How Effective are Fiscal Incentives for R\&D? A Review of the Evidence", Research Policy 29, 449-469."

Himmelberg, Charles and Bruce Peterson (1994), "R\&D and internal finance: a panel data study of small firms in high tech industries", Review of Economics and Statistics 76(1):38-51

Jacob, Brian and Lars Lefgren (2007) "The Impact of grant funding on scientific productivity" NBER Working Paper No. 02138

Jones, Ben (2005) "Age and Great Invention" NBER Working Paper No. 11359 
Issued in May.

National Academy of Sciences (2006) The Gathering Storm

IPAMM, Impact of Proposal and Award Management Mechanisms Final Report to the National Science Board August 8, 2007

Jackson, Shirley Ann (2003), Envisioning a $21^{\text {st }}$ Century Science and Engineering Workforce for the United States: tasks for university, industry and government National Academy of Science

Jones, Chad and John Williams. (1998) "Measuring the Social Rate of Return to R\&D", Quarterly Journal of Economics, 113(4), 119-35.

Keller, Wolfgang (2004) "International Technology Diffusion" Journal of Economic Literature, 42(3), 752-782

Mervis, Jeffrey, "Going from RAGS to riches is proving to be very difficult" Science, May 9, 2008, pp 728-729

National Academy of Science (2005) Bridges to Independence: fostering the independence of new investigators in biomedical sciences

National Academy of Science (2006) The Gathering Storm

National Research Council (1998) Trends in the Early Careers of Life Scientists.

National Science Foundation (2004), Division of Science Resources Statistics, Federal Funds for Research and Development: Fiscal Years 1970-2003; Federal Obligations for Research by Agency and Detailed Field of Science and Engineering, NSF 04-335

National Science Foundation (2007), Impact of Proposal and Award Management Mechanisms Final Report

National Science Foundation (2008) Science and Technology Indicators

Progressive Policy Institute (2002)

http://www.neweconomyindex.org/states/2002/index.html

Romer, Paul (1989) "Endogenous technical change" Journal of Political Economy, 98: S71-S102

Sachs, Frederick (November 19, 2007) "Is the NIH Budget Saturated? Why hasn't more funding meant more publications?" (www.the-scientist.com/news/print/53580

Weller, Christian and Wheeler, Holly (2008) "Nothing to Brag About" American 
Progress Institute

http://zed.techprogress.org:8080/mysite/sprint/issues/2008/03/high_priority.html

Wilson, Daniel. (2008) "Beggar thy Neighbor? The In-State, Out-of-State and Aggregate Effects of R\&D Tax Credits" forthcoming Review of Economics and Statistics.

Zucker, Lynne, Michael Darby and Marilyn Brewer (1998) "Intellectual Property and the Birth of US Biotechnology Enterprises" American Economic Review, 88(1), pp. 290-306 
Table 1: Declining US Shares of World Science and Engineering Activity

\begin{tabular}{lll}
\hline \hline Measure of Activity & Early Period & Later Period \\
\hline \multicolumn{1}{c}{ College Enrollments } & $30 \%(1970)$ & $13 \%(2005)$ \\
$\quad$ S\&E Undergraduate & $\sim 20 \%(1970)$ & $\sim 9 \%(2004)$ \\
degrees & & \\
PhDs in S\&E granted & $40 \%(1970)$ & $15 \%(2010)$ \\
R\&D & $\sim 50 \%(1970)$ & $\sim 35 \%$ \\
ACS Chemical Abstracts & $73 \%(1980)$ & $40 \%(2003)$ \\
All Science Articles & $39 \%(1988)$ & $29 \%(2005)$ \\
All Citations & $36 \%(1992)$ & $30 \%(2002)$ \\
\hline \hline
\end{tabular}

\section{Sources:}

College enrollments, Freeman (2008), based on tertiary enrollments from United Nations Educational, Scientific and Cultural Organization, Institute for Statistics (2007). Montreal.

S\&E undergrad degrees, 2004 from NSF, Science and Engineering Indicators 2008, appendix table 2-37 excluding social sciences; 1970 estimate from Freeman (2008)

PhDs granted, R\&D, ACS chemical abstracts from Freeman (2006)

Science articles, from NSF (2008), table 5-34 and NSF (2006),

Citations from NSF (2008), appendix table 5-38 where 2002 refers to articles written in 2001-03 cited by 2005 articles (\%); 1992 refers to 1991-93 articles cited by 1995 articles 


\section{Table 2: Rationale for government support of R\&D}

\begin{tabular}{|c|c|c|c|}
\hline $\begin{array}{l}\text { Justification for } \\
\text { taxpayer support of } \\
\text { R\&D spending }\end{array}$ & $\begin{array}{l}\text { Basic research } \\
\text { (federal grants, } \\
\text { largely to } \\
\text { universities }\end{array}$ & $\begin{array}{l}\text { Applied Research } \\
\text { (e.g. R\&D tax } \\
\text { credits) }\end{array}$ & $\begin{array}{l}\text { What is the impact of } \\
\text { Globalization on the } \\
\text { rationale }\end{array}$ \\
\hline Knowledge spillovers & yes & Some & $\begin{array}{l}\text { Probably } \\
\text { rationale }\end{array}$ \\
\hline $\begin{array}{l}\text { Economic } \\
\text { Competitiveness }\end{array}$ & None/little & Yes & $\begin{array}{l}\text { Probably strengthens } \\
\text { rationale }\end{array}$ \\
\hline
\end{tabular}

Notes:- See text for a discussion 
Table 3: US Shares of USPTO Patents, Shares of World High Tech Output and Trade Balance in Manufacturing

\begin{tabular}{lllll}
\hline Measure & $\mathbf{1 9 8 0}$ & $\mathbf{1 9 9 0}$ & $\mathbf{2 0 0 0}$ & $\mathbf{2 0 0 3}$ \\
\hline $\begin{array}{l}\text { US first name inventor share } \\
\text { USPTO patent applications* }\end{array}$ & $55 \%$ & $55 \%$ & $56 \%$ & $53 \%$ \\
$\begin{array}{l}\text { US first name inventor share } \\
\text { EPO patent applications* }\end{array}$ & 27 & 27 & 26 & 23 \\
$\begin{array}{l}\text { US share of World Gross } \\
\text { Revenue in High Tech }\end{array}$ & 28 & 25 & 38 & 39 \\
$\begin{array}{l}\text { US share of World Value } \\
\text { added in High Tech }\end{array}$ & 25 & 25 & 40 & 42 \\
$\begin{array}{l}\text { US share of World Exports } \\
\text { in High Tech }\end{array}$ & 30 & 23 & 18 & 15 \\
$\begin{array}{l}\text { US share of World Imports } \\
\text { in High Tech }\end{array}$ & 13 & 18 & 20 & 17 \\
$\begin{array}{l}\text { US trade balance in High } \\
\text { Tech (\$Billion) }\end{array}$ & +34 & +27 & -40 & -90 \\
\hline
\end{tabular}

Notes: * Patent statistics refer to 1985 as first year rather than 1980; 2005 (USPTO and 2006 (EPO) as last year rather than 2003

"High-technology manufacturing industries" as classified by Organisation for Economic Co-operation and Development include aerospace, communications equipment, office machinery and computers, pharmaceuticals, and scientific instruments. Value added revenue excludes purchases of domestic and imported materials and inputs. Constant dollar data for foreign countries calculated by deflating industry data valued in each country's nominal domestic currency with a sector-specific price index constructed for that country and then converted to U.S. dollars based on average annual exchange rates.

Source: National Science Foundation (2008) table 6.31 and table 6.32 for USPTO patent data, table 6-41 and 6-42 for EPO patent data; table 6.8 and 6.9 for value added. Table 6.14 and 6.15 for total revenue, exports and imports. 
Table 4: Applications, Awards, and Success Rates for RO1 and Equivalent Grants, by status of applicant

\begin{tabular}{|c|c|c|c|c|c|}
\hline & 1980 & 1998 & 2003 & 2006 & 2007 \\
\hline \multicolumn{6}{|l|}{ POTENTIAL FIRST } \\
\hline \multicolumn{6}{|l|}{ TIME AWARDEES } \\
\hline Applications & 8,515 & 6,817 & 8,377 & 9,399 & -- \\
\hline Awards & 1,903 & 1,484 & 1,720 & 1,384 & 1,663 \\
\hline Success rate & $22.3 \%$ & $21.3 \%$ & $20.5 \%$ & $14.7 \%$ & -- \\
\hline $\begin{array}{l}\% \text { of successful with } \\
\text { original proposal }\end{array}$ & 86 & 61 & 49 & 34 & 28 \\
\hline $\begin{array}{l}\% \text { of successful with First } \\
\text { amendment }\end{array}$ & 13 & 29 & 38 & 40 & 41 \\
\hline \multicolumn{6}{|l|}{ EXPERIENCED } \\
\hline \multicolumn{6}{|l|}{ (PREVIOUSLY } \\
\hline \multicolumn{6}{|l|}{ FUNDED) APPLICANTS } \\
\hline Applications & 7,404 & 13,666 & 16,325 & 19,822 & -- \\
\hline Awards & 3,240 & 4,782 & 5,730 & 4,677 & \\
\hline Success rate & $43.8 \%$ & $35.0 \%$ & $35.1 \%$ & $23.6 \%$ & \\
\hline
\end{tabular}

Source: appendix A table, from

grants.nih.gov/grants/new_investigators/Workforce_Info09072007.ppt - 09-19-2007 - 
Table 5: The reduced chance of getting NIH R01 grants and the increased number of submissions needed to get an NIH grant

\section{(a) New Submissions}

\begin{tabular}{lllll}
\hline \hline & $\mathbf{1 9 9 7}$ & $\mathbf{2 0 0 3}$ & $\mathbf{2 0 0 6}$ & $\mathbf{2 0 0 7}$ \\
\# Submissions & 14,814 & 18,738 & 22,150 & 20,651 \\
\# awards & 3,476 & 4,526 & 3,612 & 3,961 \\
Success rate & $23.5 \%$ & $24.2 \%$ & $16.3 \%$ & $19.2 \%$ \\
$\quad$ For original submission & $18.7 \%$ & $17.0 \%$ & $7.9 \%$ & $8.4 \%$ \\
& & & & \\
Proportion winning on original submit & $55 \%$ & $51 \%$ & $32 \%$ & $28 \%$ \\
Average \# submissions per award & 1.6 & 1.7 & 2.0 & 2.1 \\
Average Value of Award & & & & \\
\hline \hline
\end{tabular}

\section{(b) Continuation Grants}

\begin{tabular}{lllll}
\hline \hline & $\mathbf{1 9 9 7}$ & $\mathbf{2 0 0 3}$ & $\mathbf{2 0 0 6}$ & $\mathbf{2 0 0 7}$ \\
\# Submissions & 5,510 & 5,785 & 6,830 & 6,586 \\
\# awards & 2,624 & 2,858 & 2,388 & 2,468 \\
Success rate & $47.6 \%$ & $49.4 \%$ & $35.0 \%$ & $37.5 \%$ \\
$\quad$ For original submission & $47.5 \%$ & $40.2 \%$ & $25.7 \%$ & $25.2 \%$ \\
& & & & \\
Proportion winning on original submit & $44 \%$ & $61.8 \%$ & $41.8 \%$ & $36.8 \%$ \\
Average \# submissions per award & 1.4 & 1.5 & 1.8 & 1.9 \\
& & & & \\
Average Value of Award & $\$ 261,662$ & $\$ 357,103$ & $\$ 374,288$ & $\$ 386,507$ \\
\hline \hline
\end{tabular}

Source: Office of Extramural Research, NIH, "Success Rates for NIH Type 1

Competing Research Project Applications,"

http:/grants.nih.gov/grants/award/success.htm, excel file, by amendment status. 
Table 6: National Science Foundation Research Proposals and Awards, 1997-2006

\begin{tabular}{lcc}
\hline \hline & $\mathbf{1 9 9 7}$ & $\mathbf{2 0 0 6}$ \\
\hline & 19935 & 31514 \\
Competitive proposals & 5961 & 6708 \\
Competitive awards & $30 \%$ & $21 \%$ \\
Funding rate & 1.7 & 2.2 \\
Proposal Submitted per PI & & \\
receiving one award & $\$ 78,223$ & $\$ 134,595$ \\
Average mean award size &
\end{tabular}

Source : IPAMM, figure 2, figure 3, figure 4 
Figure 1: Business Enterprise Research and Development (BERD) as a percentage of GDP in Selected Countries

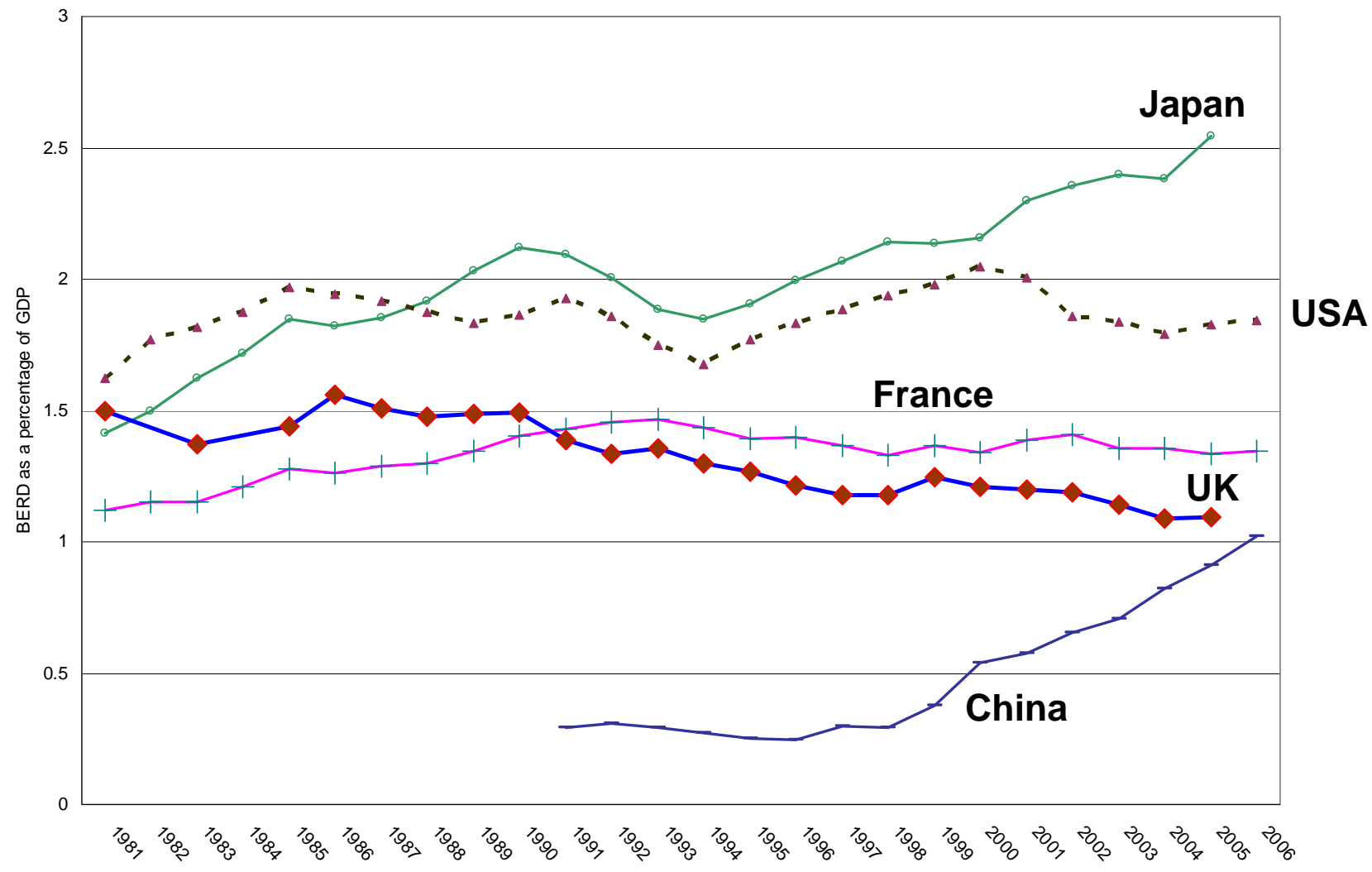

Source : Authors' calculations from OECD data, various years 
Figure 2:

The Acceleration and Deceleration of NIH Spending under the "doubling goal"

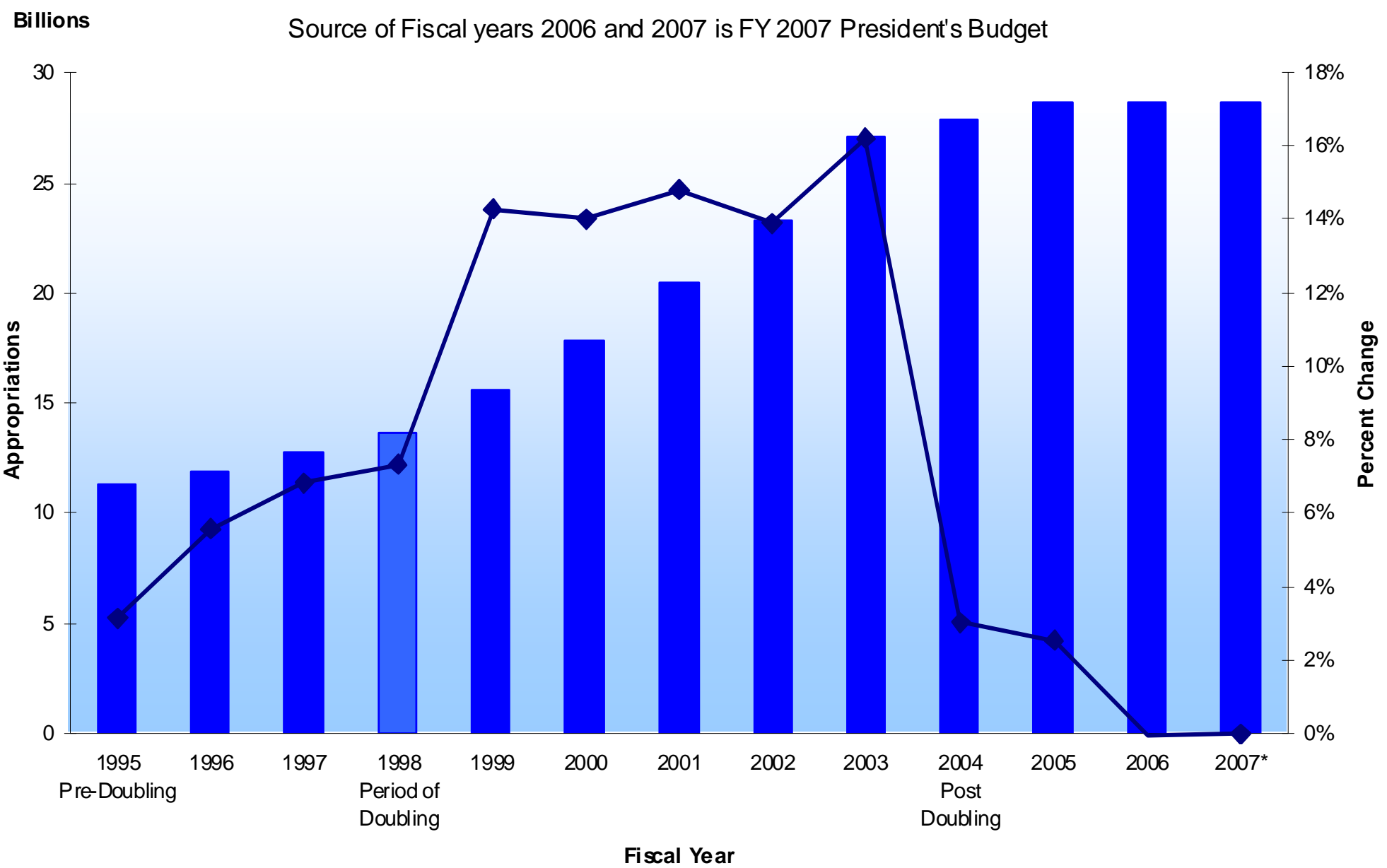

Appropriation $\_$Percent change from previous fiscal year 
Figure 3: Comparison between Doubling research and the socially optimal path of increase

optimal stock $\_$actual stock

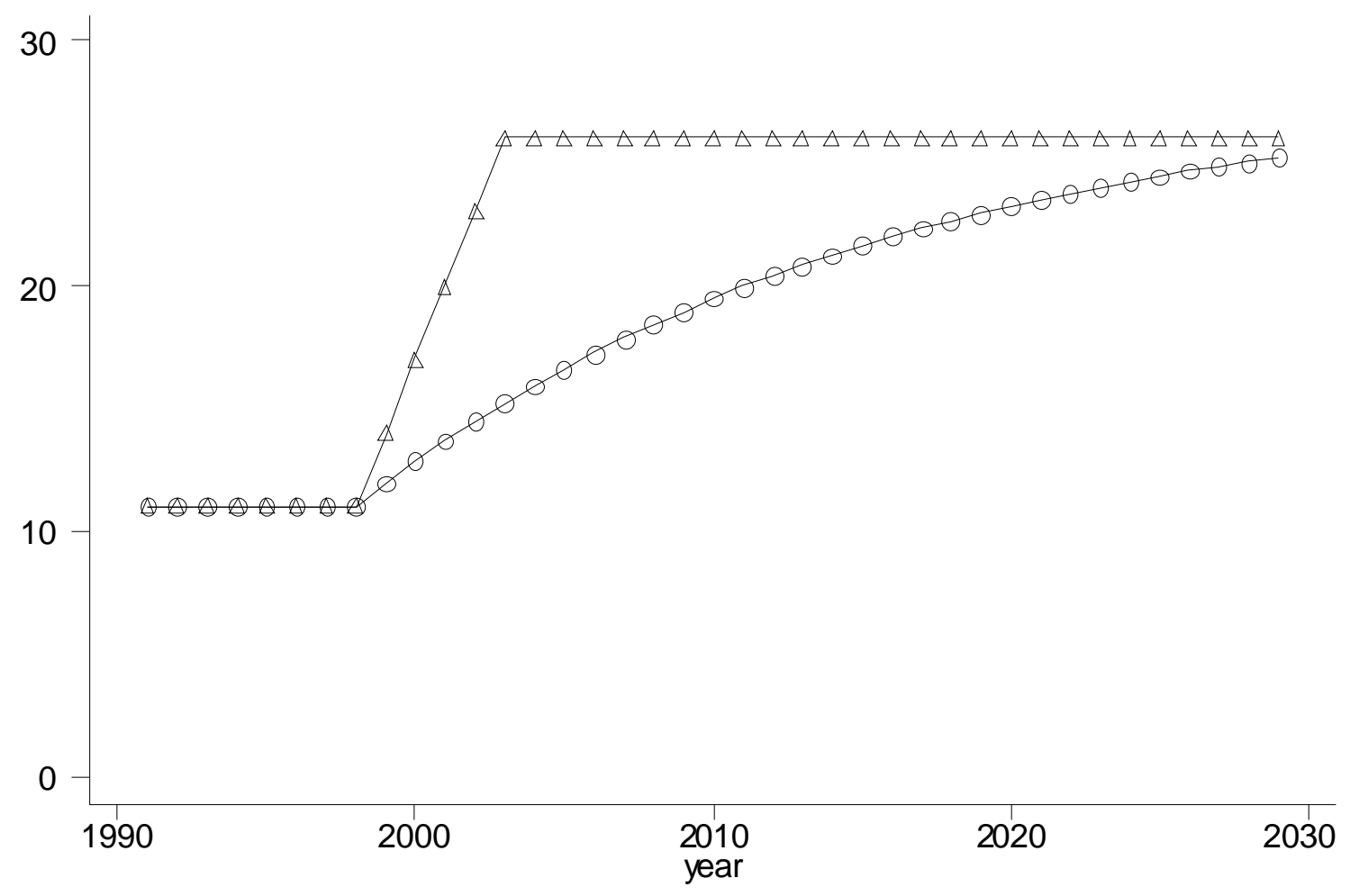

Notes: this compares a stylized version of the doubling of NIH funding to an optimal path when adjustment costs are convex. 
Figure 4: The increase in the ratio of Post Docs to Principal Investigators In US Biomedical Labs and the Increase in Foreign Born Post Docs compared to US pos-docs.

A) Postdocs compared to PIs

\section{STAFF IN US BIOMEDICAL LABS}

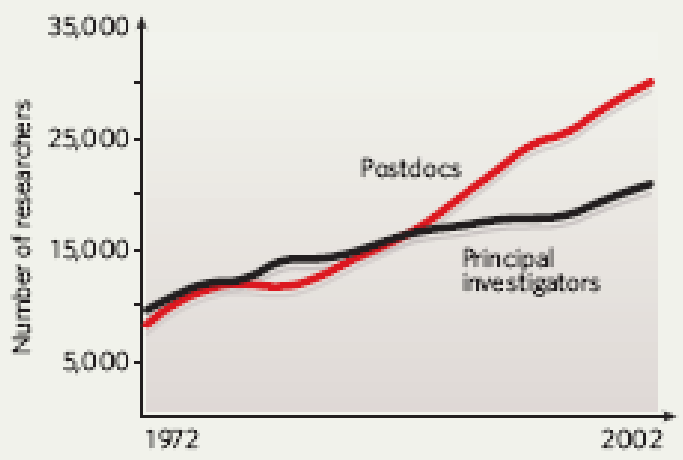

B) US vs. Foreign-Born Post Docs

Figure 2-32

Postdoctoral students at U.S. universities, by citizenship status: 1985-2005

Thousands

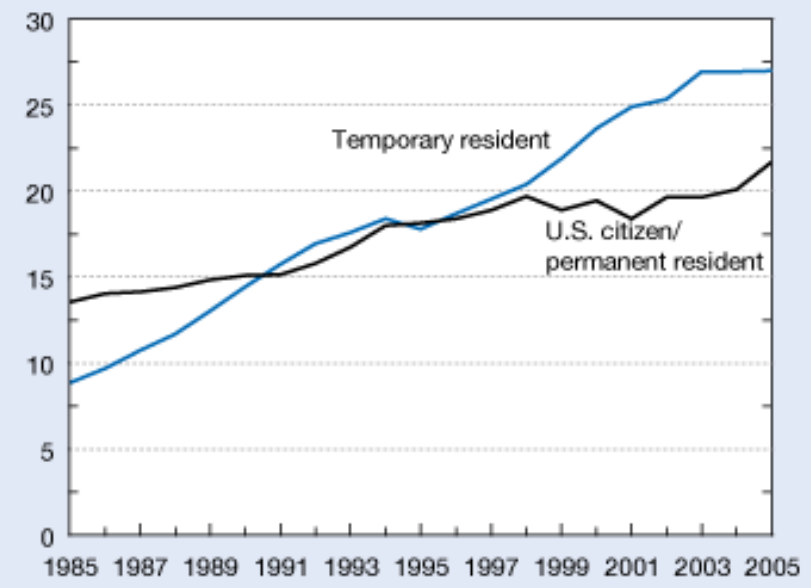

SOURCE: National Science Foundation, Division of Science Resources Statistics, Survey of Graduate Students and Postdoctorates in Science and Engineering, WebCASPAR database, http://webcaspar.nsf.gov. See appendix table 2-34.

Science and Engineering Indicators 2008 
Figure 5: Number of Persons $<35$ years old getting RO1s

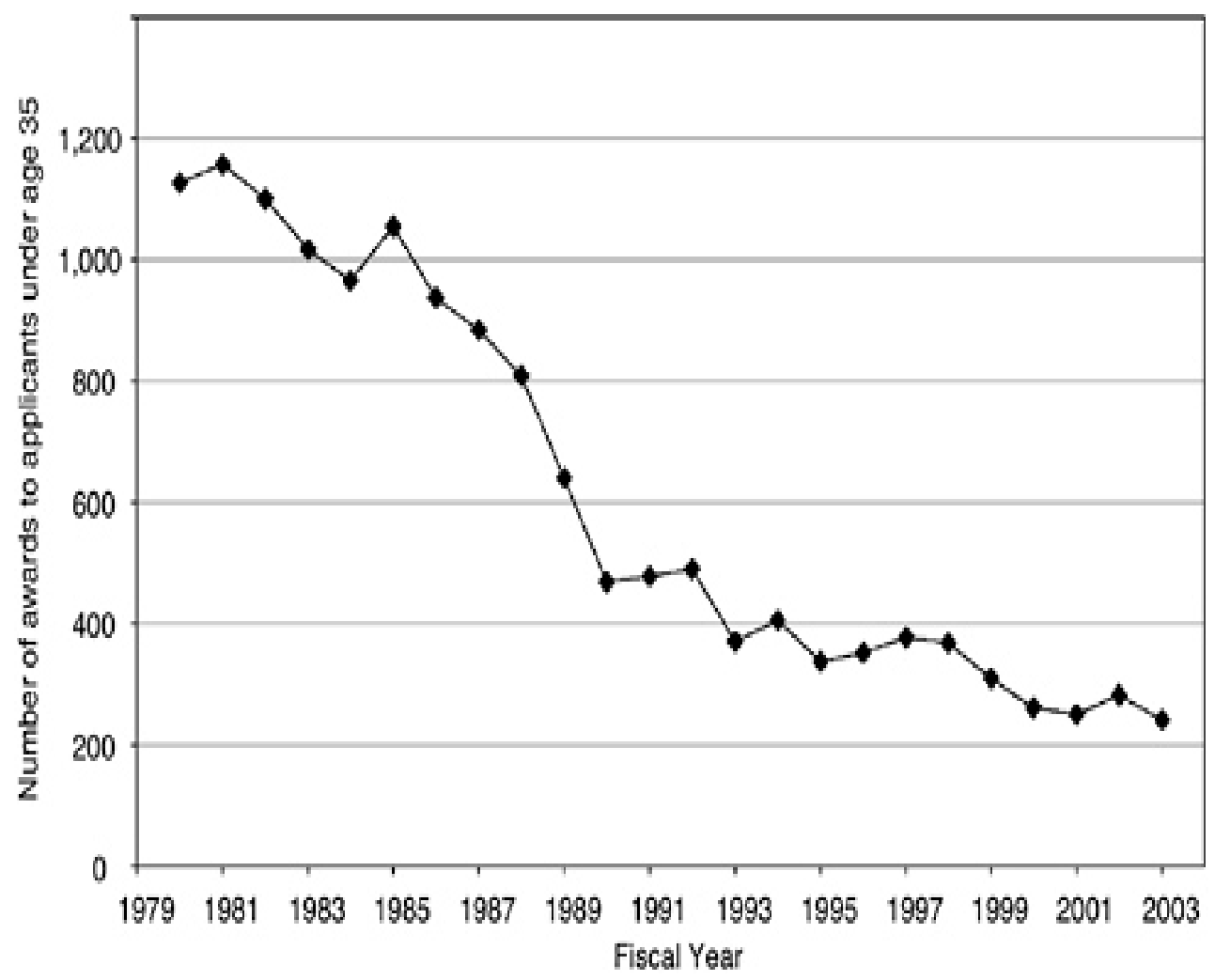




\section{Appendix A: Additional data}

Table A1:

SUCCESS AND FUNDING RATES OF FIRST TIME AND PREVIOUSLY FUNDED APPLICANTS

Fiscal Years 1980 - 2006

\begin{tabular}{|c|c|c|c|c|c|c|c|c|c|c|c|c|}
\hline & \multicolumn{6}{|c|}{ Potential First Time Awardee } & \multicolumn{6}{|c|}{ Experienced (Previously Funded) Applicants } \\
\hline FY & Applications & Awarded & $\begin{array}{c}\text { Success } \\
\text { rate }\end{array}$ & Applicants & Awardees & $\begin{array}{c}\text { Funding } \\
\text { Rate }\end{array}$ & Applications & Awarded & $\begin{array}{c}\text { Success } \\
\text { rate }\end{array}$ & Applicants & Awardees & $\begin{array}{c}\text { Funding } \\
\text { Rate }\end{array}$ \\
\hline \multicolumn{13}{|c|}{ R01 Equivalent (R01, R23, R29, R37) } \\
\hline 1980 & 8,515 & 1,903 & $22.3 \%$ & 7,949 & 1,859 & $23.4 \%$ & 7,404 & 3,240 & $43.8 \%$ & 6,093 & 2,992 & $49.1 \%$ \\
\hline 1981 & 8,694 & 1,818 & $20.9 \%$ & 8,097 & 1,766 & $21.8 \%$ & 8,739 & 3,482 & $39.8 \%$ & 7,100 & 3,253 & $45.8 \%$ \\
\hline 1982 & 8,106 & 1,598 & $19.7 \%$ & 7,523 & 1,572 & $20.9 \%$ & 9,937 & 3,628 & $36.5 \%$ & 7,868 & 3,361 & $42.7 \%$ \\
\hline 1983 & 7,568 & 1,650 & $21.8 \%$ & 6,948 & 1,607 & $23.1 \%$ & 9,776 & 3,777 & $38.6 \%$ & 7,797 & 3,498 & $44.9 \%$ \\
\hline 1984 & 7,440 & 1,637 & $22.0 \%$ & 6,870 & 1,612 & $23.5 \%$ & 9,934 & 3,887 & $39.1 \%$ & 8,085 & 3,627 & $44.9 \%$ \\
\hline 1985 & 7,784 & 1,845 & $23.7 \%$ & 7,013 & 1,809 & $25.8 \%$ & 11,138 & 4,341 & $39.0 \%$ & 8,917 & 4,021 & $45.1 \%$ \\
\hline 1986 & 7,305 & 1,683 & $23.0 \%$ & 6,661 & 1,658 & $24.9 \%$ & 11,302 & 4,328 & $38.3 \%$ & 9,105 & 4,004 & $44.0 \%$ \\
\hline 1987 & 7,077 & 1,657 & $23.4 \%$ & 6,388 & 1,629 & $25.5 \%$ & 11,151 & 4,744 & $42.5 \%$ & 9,066 & 4,364 & $48.1 \%$ \\
\hline 1988 & 7,774 & 1,780 & $22.9 \%$ & 7,083 & 1,741 & $24.6 \%$ & 11,565 & 4,329 & $37.4 \%$ & 9,404 & 3,989 & $42.4 \%$ \\
\hline 1989 & 7,752 & 1,621 & $20.9 \%$ & 7,068 & 1,590 & $22.5 \%$ & 11,629 & 3,782 & $32.5 \%$ & 9,430 & 3,547 & $37.6 \%$ \\
\hline 1990 & 7,838 & 1,394 & $17.8 \%$ & 7,201 & 1,371 & $19.0 \%$ & 11,997 & 3,371 & $28.1 \%$ & 9,685 & 3,146 & $32.5 \%$ \\
\hline 1991 & 7,279 & 1,560 & $21.4 \%$ & 6,652 & 1,539 & $23.1 \%$ & 11,902 & 3,932 & $33.0 \%$ & 9,653 & 3,679 & $38.1 \%$ \\
\hline 1992 & 7,200 & 1,473 & $20.5 \%$ & 6,625 & 1,451 & $21.9 \%$ & 12,602 & 4,262 & $33.8 \%$ & 10,247 & 3,988 & $38.9 \%$ \\
\hline 1993 & 8,124 & 1,269 & $15.6 \%$ & 7,408 & 1,246 & $16.8 \%$ & 13,465 & 3,690 & $27.4 \%$ & 10,831 & 3,458 & $31.9 \%$ \\
\hline 1994 & 8,832 & 1,453 & $16.5 \%$ & 7,932 & 1,425 & $18.0 \%$ & 14,337 & 4,269 & $29.8 \%$ & 11,180 & 3,931 & $35.2 \%$ \\
\hline 1995 & 7,968 & 1,420 & $17.8 \%$ & 7,217 & 1,399 & $19.4 \%$ & 14,712 & 4,514 & $30.7 \%$ & 11,458 & 4,173 & $36.4 \%$ \\
\hline 1996 & 7,017 & 1,356 & $19.3 \%$ & 6,395 & 1,336 & $20.9 \%$ & 14,043 & 4,419 & $31.5 \%$ & 11,171 & 4,102 & $36.7 \%$ \\
\hline 1997 & 6,967 & 1,484 & $21.3 \%$ & 6,313 & 1,453 & $23.0 \%$ & 13,654 & 4,751 & $34.8 \%$ & 10,862 & 4,413 & $40.6 \%$ \\
\hline 1998 & 6,817 & 1,545 & $22.7 \%$ & 6,161 & 1,505 & $24.4 \%$ & 13,666 & 4,782 & $35.0 \%$ & 10,978 & 4,400 & $40.1 \%$ \\
\hline 1999 & 7,333 & 1,596 & $21.8 \%$ & 6,592 & 1,561 & $23.7 \%$ & 14,802 & 5,515 & $37.3 \%$ & 11,834 & 5,063 & $42.8 \%$ \\
\hline 2000 & 7,479 & 1,642 & $22.0 \%$ & 6,741 & 1,596 & $23.7 \%$ & 14,750 & 5,466 & $37.1 \%$ & 11,719 & 4,998 & $42.6 \%$ \\
\hline 2001 & 7,494 & 1,629 & $21.7 \%$ & 6,691 & 1,580 & $23.6 \%$ & 14,545 & 5,361 & $36.9 \%$ & 11,625 & 4,975 & $42.8 \%$ \\
\hline 2002 & 7,632 & 1,612 & $21.1 \%$ & 6,862 & 1,574 & $22.9 \%$ & 14,640 & 5,222 & $35.7 \%$ & 11,673 & 4,815 & $41.2 \%$ \\
\hline 2003 & 8,377 & 1,720 & $20.5 \%$ & 7,380 & 1,680 & $22.8 \%$ & 16,325 & 5,730 & $35.1 \%$ & 12,647 & 5,243 & $41.5 \%$ \\
\hline 2004 & 9,413 & 1,578 & $16.8 \%$ & 8,147 & 1,528 & $18.8 \%$ & 18,241 & 5,457 & $29.9 \%$ & 13,863 & 4,999 & $36.1 \%$ \\
\hline 2005 & 9,365 & 1,475 & $15.8 \%$ & 8,195 & 1,441 & $17.6 \%$ & 19,175 & 5,014 & $26.1 \%$ & 14,410 & 4,631 & $32.1 \%$ \\
\hline 2006 & 9,399 & 1,384 & $14.7 \%$ & 8,180 & 1,354 & $16.6 \%$ & 19,822 & 4,677 & $23.6 \%$ & 14,766 & 4,350 & $29.5 \%$ \\
\hline
\end{tabular}


Table A2: NIH CHANGES IN NUMBERS OF GRANTS AND DOLLAR SUPPORT

\begin{tabular}{|c|c|c|c|}
\hline \multirow{2}{*}{$\begin{array}{l}\text { Fiscal } \\
\text { Year }\end{array}$} & \multirow{2}{*}{$\begin{array}{l}\text { Total Amount } \\
\text { Awarded }\end{array}$} & \multicolumn{2}{|c|}{ Research Grants } \\
\hline & & $\begin{array}{l}\text { Number } \\
\text { of } \\
\text { Awards }\end{array}$ & Award Amount \\
\hline 2007 & $\$ 21,263,805,742$ & 47,181 & $\$ 20,415,899,325$ \\
\hline 2006 & $\$ 23,182,959,918$ & 46,797 & $\$ 20,154,363,154$ \\
\hline 2005 & $\$ 23,410,118,044$ & 47,345 & $\$ 20,206,478,806$ \\
\hline 2004 & $\$ 22,900,576,587$ & 47,464 & $\$ 19,607,812,023$ \\
\hline 2003 & $\$ 21,866,798,411$ & 46,081 & $\$ 18,461,462,170$ \\
\hline 2002 & $\$ 19,074,464,796$ & 43,520 & $\$ 16,830,194,185$ \\
\hline 2001 & $\$ 16,784,681,877$ & 40,666 & $\$ 14,907,921,291$ \\
\hline 2000 & $\$ 14,791,024,329$ & 38,302 & $\$ 13,002,656,762$ \\
\hline 1999 & $\$ 12,855,628,060$ & 35,870 & $\$ 11,228,665,952$ \\
\hline 1998 & $\$ 11,179,749,719$ & 33,703 & $\$ 9,801,789,027$ \\
\hline 1997 & $\$ 10,456,030,704$ & 32,109 & $\$ 9,046,542,619$ \\
\hline
\end{tabular}

Report Date: 2/12/08 


\section{Appendix B: Modeling researcher responses to short run changes in numbers of awards - A simple model of scientist behaviour}

\section{INDIVIDUAL BEHAVIOR}

There are a pool of $L$ potential researchers who submit either 0,1 or 2 research bids ${ }^{24}$. If they submit they have a probability $p$ of winning an award. This will be a function of researcher quality, $z$, and the number of awards made available by the government, $N$ (we take these as exogenous common knowledge) so $p=f(Z, N$,. $)$ and is increasing in both arguments. Let us assume that the support of the distribution of researcher quality is $[0,1]$. A researcher is only allowed to accept a maximum of one award at a time (so if he wins two he can only take one). Winning an award gives value to the researcher (funds) of $V$, losing is normalized to zero. The cost of putting a bid together is $c$.

The net utility of submitting one bid is $\mathrm{u}(1)^{25}$

$u(1)=p V-c$

The net utility of submitting two bids is $\mathrm{u}(2)$

$u(2)=\left(1-(1-p)^{2}\right) V-2 c=p(2-p) V-2 c$

A scientist will not submit a bid if $u(1)<0$, i.e. $p<\frac{c}{V}$.

Define the benefit-cost ratio as $\beta=\mathrm{V} / \mathrm{c}$ and the threshold probability as $\widetilde{p}=\frac{1}{\beta}$. Thus if $p<\widetilde{p}$ the researcher will choose not to bid.

When will the scientist put in two bids? This will occur if $u(2)>u(1)$. This condition can be written as

\footnotetext{
${ }^{24}$ For simplicity we cap the maximum number of bids as two, but consider larger number of bids in the extensions below.

${ }^{25}$ The model assumes risk neutrality. If we incorporate risk aversion the same basic intuitions come
} 
$-\beta p^{2}+\beta p-1>0$

This quadratic form has two solutions that define two more threshold value of $\mathrm{p}$ :

$\underline{p}=\frac{1}{2}\left[1-\sqrt{\left(1-\frac{4}{\beta}\right)}\right]$ and $\bar{p}=\frac{1}{2}\left[1+\sqrt{\left(1-\frac{4}{\beta}\right)}\right]$

subject to the regularity conditions that the value of $\beta$ must allow $\mathrm{p}$ to be defined on the $(0,1)$ support (e.g. $\beta>4)$.

These three thresholds define scientist behavior over four regimes (see Figure A1).

(A) $p<\widetilde{p}$ researcher will bid zero.

(B) $\widetilde{p}<p<\underline{p}$ researcher will make one bid

(C) $\underline{p}<p<\bar{p}$ researcher will make two bids

(D) $\bar{p}<p$ researcher will make one bid.

The intuition is the following. In Regime (A), the probability of winning is too low to cover the costs (in expected terms). In regime (D), "star scientist" the probability of winning is so high that there is not much benefit from a second bid. In Regime (C), the chances of winning are not quite so high, so researcher finds it pays to take out a second ticket. In Regime (B) it is worth making a bid, but because these scientists are on the margin ("marginal quality") of not bidding, they do not find it is worth the cost of two bids.

\section{Comparative statics in $\beta$}

If the value of the award rises ( $\beta$ up) then this will change the thresholds. $\widetilde{p}$ will fall, $\underline{p}$ will fall and $\bar{p}$ will rise. This means (a) there will be a larger number of bids, (b) there will be larger number of scientists making two bids

through. 


\section{EQUILIBRIUM}

There are $M$ bidders, $L$ potential bidders and a total number $N$ of awards available. In a rational expectations equilibrium the probabilities have to adjust so that the number of awards given out equals the expected ex ante probability of success integrated across all scientists. In our simple case:

$M \int_{0}^{1} p(z, N) d p=N$

Since $p$ and $M$ are now endogenous we must solve the model in terms of the exogenous variables $z$ and $N$. We can define analogous thresholds to $(\tilde{p}, \underline{p}$ and $\bar{p})$ in the space of researcher quality $(\widetilde{z}, \underline{z}$ and $\bar{z})$. These can be written as functions of the benefit-cost ratio, $\beta$ and the number of potential awards.

\section{$\underline{\text { Comparative statics in } \underline{\beta}}$}

If the number of awards falls all the thresholds shift to the right. The probability of winning a bid will fall so fewer scientists will submit any bids. Similarly if the number of awards rises then the thresholds shift to the left and there are more bids.

In terms of the numbers making two bids, this depends on the functional forms and the magnitude of the change in $N$. The following seems like a reasonable description of the doubling and post-doubling period, however. During the doubling period the thresholds all shift to the left but the proportion of (potential $L$ ) scientists in Regime C who make two bids stays the same $(\bar{z}-\underline{z})$.

Compare this to the post-doubling period. We keep $(\bar{z}-\underline{z})$ the same, but all thresholds have moved to the right so there is a smaller margin of scientists in Regime D. This means that of all the winning bids, the proportion of scientists submitting two bids has increased (i.e. $(\bar{z}-\underline{z}) /(1-\widetilde{z})$ is larger). 
The intuition is clear. During the post-doubling period many of the "star scientists" during the doubling period can no longer feel confident in winning an award, so they put in two awards to increase their probability of a successful draw.

These ideas are illustrated in Figures A2 and A3. 


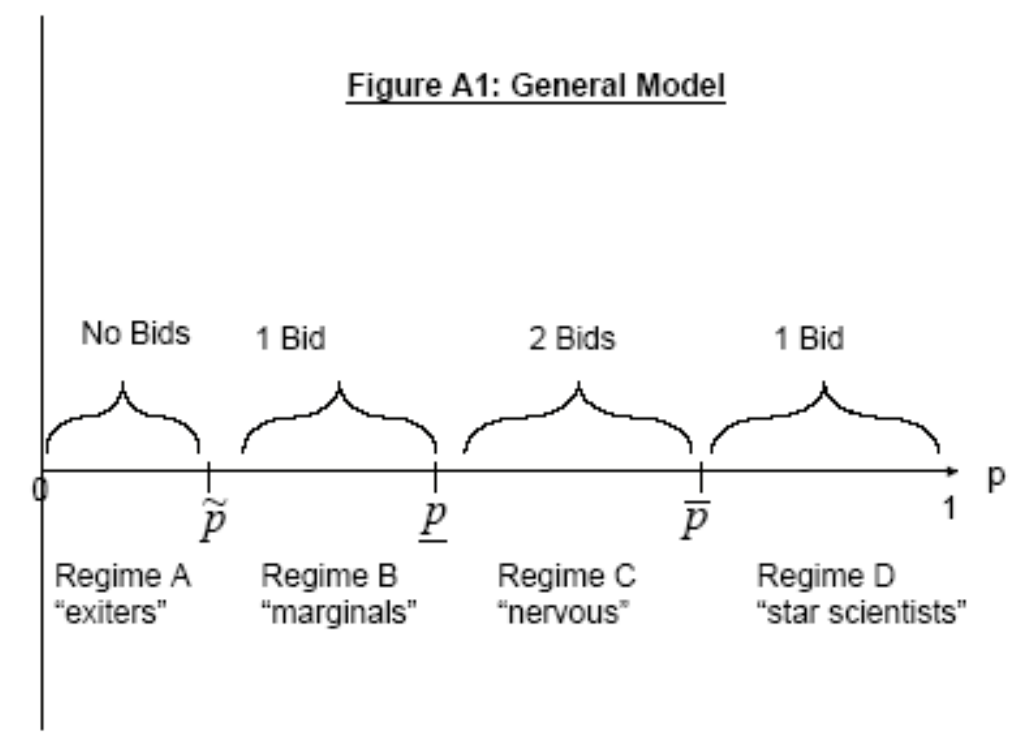

Notes: $p$ is the probability of winning an award, the three cut-off probabilities Define the thresholds. See text for details 


\section{Figure A2: Doubling period - more awards and more bids}

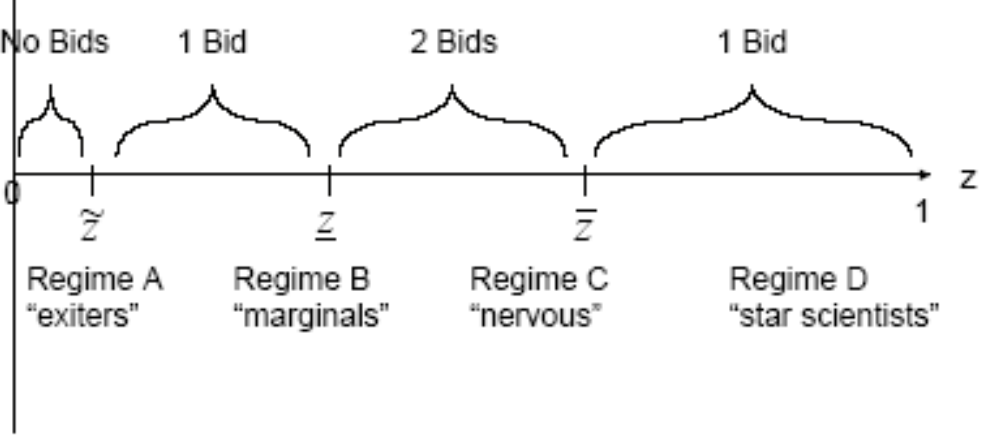

Notes: $z$ is researcher quality. See text for details 


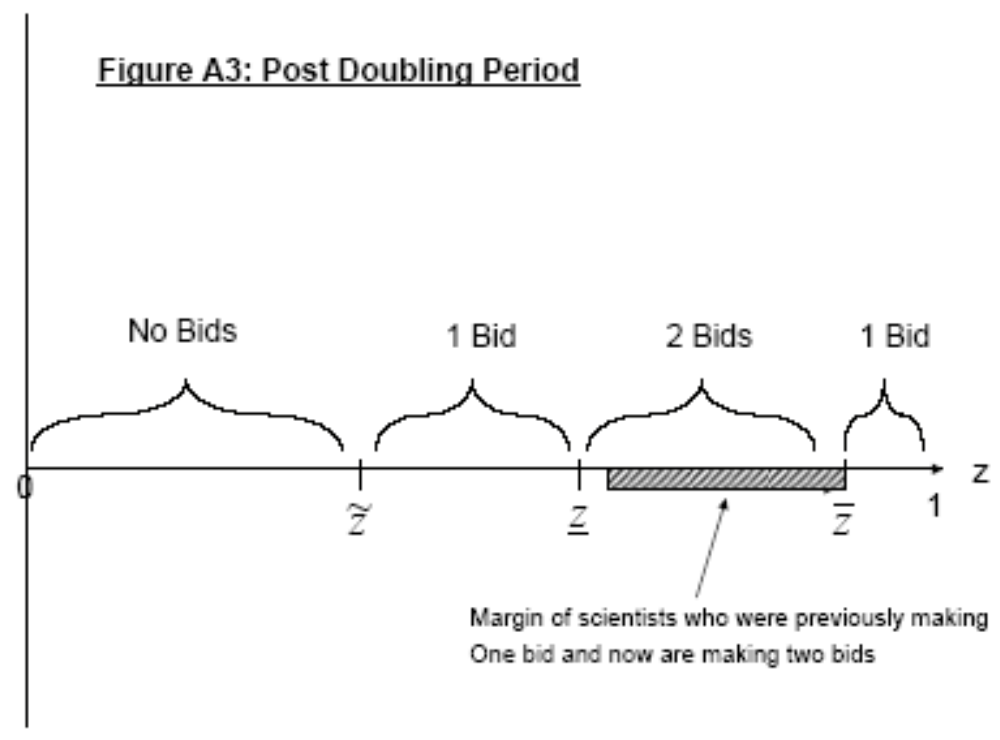

Notes: $z$ is researcher quality. See text for details 


\section{CENTRE FOR ECONOMIC PERFORMANCE \\ Recent Discussion Papers}

930 Hector Calvo-Pardo Caroline Freund Emanuel Ornelas

929 Dan Anderberg Arnaud Chevalier Jonathan Wadsworth

928 Christos Genakos Mario Pagliero

927 Nick Bloom Luis Garicano Raffaella Sadun John Van Reenen

926 Reyn van Ewijk

925 Stephen J. Redding

924 Rafael Gomez Alex Bryson Tobias Kretschmer Paul Willman

923 Bianca De Paoli

922 L. Rachel Ngai Silvana Tenreyro

921 Kosuke Aoki Gianluca Benigno Nobuhiro Kiyotaki

920 Alex Bryson John Forth Patrice Laroche

919 David Marsden Simone Moriconi

918 Richard Layard Guy Mayraz Stephen Nickell
The ASEAN Free Trade Agreement: Impact on Trade Flows and External Trade Barriers

Anatomy of a Health Scare: Education, Income and the MMR Controversy in the UK

Risk Taking and Performance in Multistage Tournaments: Evidence from Weightlifting Competitions

The Distinct Effects of Information Technology and Communication Technology on Firm Organization

Long-term health effects on the next generation of Ramadan fasting during pregnancy

The Empirics of New Economic Geography

Employee Voice and Private Sector Workplace Outcomes in Britain, 1980-2004

Monetary Policy Under Alterative Asset Market Structures: the Case of a Small Open Economy

Hot and Cold Seasons in the Housing Market

Capital Flows and Asset Prices

Unions and Workplace Performance in Britain and France

'The Value of Rude Health': Employees' Well Being, Absence and Workplace Performance

Does Relative Income Matter? Are the Critics Right? 
917 Ralf Martin

Laure B. de Preux

Ulrich J. Wagner

916 Paul-Antoine Chevalier

Rémy Lecat

Nicholas Oulton

915 Ghazala Azmat

Nagore Iriberri

914 L Rachel Ngai

Robert M. Samaniego

913 Francesco Caselli

Tom Cunningham

912 Marco Manacorda

Edward Miguel

Andrea Vigorito

911 Philippe Aghion

John Van Reenen

Luigi Zingales

910 Fabian Waldinger

909 Tomer Blumkin

Yossi Hadar

Eran Yashiv

908 Natalie Chen

Dennis Novy

907 Dongshu Ou

906 Andrew B. Bernard

J. Bradford Jensen

Stephen J. Redding

Peter K. Schott

905 Gianluca Benigno

Bianca De Paoli

904 Stephen J. Redding
The Impacts of the Climate Change Levy on

Business: Evidence from Microdata

Convergence of Firm-Level Productivity,

Globalisation, Information Technology and

Competition: Evidence from France

The Importance of Relative Performance

Feedback Information: Evidence from a

Natural Experiment using High School

Students

Accounting for Research and Productivity

Growth Across Industries

Leader Behavior and the Natural Resource

Curse

Government Transfers and Political Support

Innovation and Institutional Ownership

Peer Effects in Science - Evidence from the Dismissal of Scientists in Nazi Germany

The Macroeconomic Role of Unemployment Compensation

International Trade Integration: A

Disaggregated Approach

To Leave or Not to Leave? A Regression

Discontinuity Analysis of the Impact of Failing the High School Exit Exam

The Margins of US Trade

On the International Dimension of Fiscal

Policy

Economic Geography: A Review of the

Theoretical and Empirical Literature

The Centre for Economic Performance Publications Unit Tel 02079557284 Fax 02079557595 Email info@cep.lse.ac.uk Web site http://cep.lse.ac.uk 